\title{
Evaluation of methane production from the anaerobic co-digestion of manure of guinea pig with lignocellulosic Andeans residues
}

\section{Orlando Washinton Meneses Quelal}

Universitat Politècnica de València: Universitat Politecnica de Valencia

\section{Borja Velázquez-Martí ( $\square$ borvemar@dmta.upv.es)}

Universitat Politècnica de València: Universitat Politecnica de Valencia https://orcid.org/0000-00028157-0421

\section{Juan Gaibor Chavez}

Universidad Estatal de Bolívar: Universidad Estatal de Bolivar

\section{Zulay Niño Ruiz}

IKIAM: Universidad Regional Amazonica IKIAM

\section{Andrés Ferrer Gisbert}

Universitat Politècnica de València: Universitat Politecnica de Valencia

\section{Research Article}

Keywords: fermentation, lignocellulosic waste, biogas, co-substrate, guinea pig, inoculum, kinetic model.

Posted Date: April 6th, 2021

DOl: https://doi.org/10.21203/rs.3.rs-305278/v1

License: (9) (1) This work is licensed under a Creative Commons Attribution 4.0 International License. Read Full License

Version of Record: A version of this preprint was published at Environmental Science and Pollution Research on August 7th, 2021. See the published version at https://doi.org/10.1007/s11356-021-15610$\mathrm{x}$. 


\title{
Evaluation of methane production from the anaerobic co-digestion of manure of guinea pig with lignocellulosic Andeans residues
}

Orlando Washinton Meneses Quelal ${ }^{(1)}$, Borja Velázquez-Martí( ${ }^{(1)}$, Juan Gaibor Chávez ${ }^{(2)}$, Zulay Niño Ruiz ${ }^{(3)}$, Andrés Ferrer Gisbert ${ }^{(1)}$

${ }^{1)}$ Departamento de Ingeniería Rural y Agroalimentaria. Universitat Politècnica de Valencia. Camino de Vera s/n, 46022 Valencia, España.

2) Departamento de Investigación, Centro de Investigación del Ambiente, Universidad Estatal de Bolívar, Guaranda, Ecuador

${ }^{3)}$ Laboratorio de Biomasa. Biomass to Resources Group. Universidad Regional Amazónica Ikiam. Vía Tena Muyuna Kilómetro 7, Tena, Napo, Ecuador

\begin{abstract}
The objective of this research was to evaluate the anaerobic co-digestion of guinea pig manure (CY) with Andean agricultural residues such as amaranth (AM), quinoa (QU) and wheat (TR) in batch biodigesters under mesophilic conditions $\left(37^{\circ} \mathrm{C}\right)$ for 40 days. As microbial inoculum, sewage treatment sludge was used in two inoculum/substrate ratios (ISR of 1 and 2). In terms of methane production, the best results occurred in the treatments that contained AM and QU as cosubstrate and an ISR of 2. Thus, the highest methane production occurred in the CY:AM biodigesters (25:75) and CY:QU (25:75) with $341.86 \mathrm{mlCH}_{4} / \mathrm{g}$ VS and $341.05 \mathrm{mlCH}_{4} / \mathrm{g} \mathrm{VS}$, respectively. On the other hand, the results showed that methane production with an ISR of 2 was more feasible for guinea pig waste, where the methane fraction of the biogas generated was in a range of 57 and $69 \%$. The kinetics of methane production from these raw materials was studied using five kinetic models: modified Gompertz, logistic equation, transfer, cone, and Richards. The cone model was the one that best adjusted the experimental values with those observed with an $\mathrm{r}^{2}$ of 0.999 and an RMSE of $1.16 \mathrm{mlCH}_{4} / \mathrm{g}$ VS. Finally, the highest biodegradability was obtained in the CY-AM biodigesters (25:75) with $67.92 \%$.
\end{abstract}


Keywords: fermentation, lignocellulosic waste, biogas, co-substrate, guinea pig, inoculum, kinetic model.

\section{Introduction}

This work has been carried out to analyse applicable technologies in Andean areas of South America where the conventional energy supply is deficient, both in electricity and gas, often non-existent (Omambia et al., 2017). Currently, many people in these areas still depend exclusively on organic fuels from their agricultural and livestock activities, such as firewood and dried manure, to meet their daily heating and cooking needs (He et al., 2010). The improvement of techniques to optimize its performance is necessary, under the conditions of economic, social and environmental sustainability, since it has to be integrated into a traditional way of life, and that these are socially accepted by users (Garfí et al., 2016). Increasing access to technified rural energy is essential to counteract the problems of these depressed areas and offer development possibilities (Sheinbaum and Ruiz, 2012). In the same way, deforestation and the reduction of greenhouse gas emissions would be avoided (Azevedo and Moutinho, 2018; Pérez et al., 2014).

Most of the Andean communities base their economy mainly on self-sufficient agriculture and family farming (Garfí et al., 2019; Rivera et al., 2020; Melby et al., 2020). Its agricultural activities are of an agropastoral nature and are developed in semi-arid areas at high altitude where there is a great variety of microclimatic and ecosystems (Góngora, 2003). In the higher areas, the raising of guinea pigs (Cavia porcellus) constitutes one of the main agricultural activities. The guinea pig $(\mathrm{CY})$ is one of the most common animals in rural communities in the Andes (Garfí et al., 2011; Kouakou et al., 2013). It is distributed by the countries of Peru, Ecuador, Bolivia and Colombia, and was domesticated between 2,500 and 3,600 years ago (Cedano et al., 2020; Sánchez et al., 2018). In this sense, the production of guinea pigs and their use has a high degree of 
interest for the sustainability of the area, associated with its traditional and ethnic/regional character (Góngora, 2003; García, 2019). At present, CY manure has been little explored for energy purposes, which has made these resources undervalued (Gonzalez et al., 2014; Garfí et al., 2019). The conversion of this waste into bioenergy is of special interest in this scenario. One way to address the energy needs of Andean communities is through the production of biogas through the anaerobic digestion (AD) of agricultural and livestock waste.

The application of anaerobic digestion to guinea pig manures has been little studied. In this the main reference has been Garfí et al. (2011), who warned of the scientific interest in the characterization of this process for the production and use of biogas in the Andean context. Above all, because $\mathrm{CY}$ manure has a high content of nutrients $\left(\mathrm{P}_{-} \mathrm{P}_{2} \mathrm{O}_{5}, \mathrm{~K}-\mathrm{K}_{2} \mathrm{O}\right.$, $\mathrm{N}-\mathrm{NH}_{4}$ ), and is a potential waste with multiple benefits, especially in the production of biogas and in the production of organic fertilizer (Boronat, 2013). Manure contains a C/N ratio of $14-17$, values very similar to those of sheep manure $(\mathrm{C} / \mathrm{N}=16)$ and higher than those of poultry manure $(\mathrm{C} / \mathrm{N}=12)$ (Barreros, 2017). Thus, anaerobic digestion (AD) represents a potential possibility to reduce the amount of waste from farms and, at the same time, constitutes an alternative to meet local energy needs by transforming CY manure into biogas (Mata et al., 2000).

In the literature there is little information on the use of guinea pig manure as a raw material for biogas production. Garfí et al. (2011) investigated the digestion of CY manure, to produce biogas, under psychrophilic conditions and with continuous digesters at high altitude. On the other hand, they also analysed the co-digestion of CY manure with cow manure, without any additional inoculum, in tubular digesters evaluating the effect of temperature at high altitude. 
The work presented here expands on Garfí's work comparing the processes of simple anaerobic digestion of CY manure with anaerobic digestion of guinea pig with inoculum from sewage sludge and the co-digestion of guinea pig with lignocellulosic materials typical of Andean agriculture, accessible in these communities. rural areas such as quinoa straw (QU), wheat (TR) and amaranth (AM). Thus, the high carbon content of the residues from crops and the rich nitrogen content of animal manure make for an optimal and balanced $\mathrm{C} / \mathrm{N}$ ratio (Wei et al., 2014). In the same way, the use of an inoculum in AD can influence the speed of the process (Bortolini et al., 2020; Parra et al., 2018; Holliger et al., 2016) affecting not only biodegradability but also the $\mathrm{CH}_{4}$ production rate (Moset et al., 2015; Raposo et al., 2011). Therefore, it is necessary to investigate the performance of CY manure digestion with other co-substrates and inoculum to observe the influence of biogas production synergy. It is intended to investigate the influence of the substrate / inoculum relationship in the improvement and optimization of the anaerobic co-digestion system with lignocellulosic materials.

\section{Materials and methods}

\subsection{Substrates and inoculum}

In this study, the CY manure, collected from the farms of the Bolívar State University, was analysed in co-digestion with three co-substrates: AM, QU and TR straw residues. As soon as the samples were collected, they were stored at $4^{\circ} \mathrm{C}$ in polyethylene bags, for conservation purposes. Before co-digestion, the AM, QU and TR residues were ground to a particle size of less than $3 \mathrm{~mm}$, using a universal cutter mill. The proportions of the substrates and co-substrates before being put into the biodigester were mixed with a kitchen blender to ensure that the experimental samples are uniform. As inoculum, sludge from a mesophilic anaerobic digester from the municipal wastewater treatment facility in Ibarra (Ecuador) was used. Before the start of the fermentation tests, the inoculum was 
pre-incubated for 5 days at room temperature $\left(10^{\circ} \mathrm{C}\right.$ at night and $25^{\circ} \mathrm{C}$ at day) to volatilize the residual biogas and deplete the easily available residual organic material. VDI 4630 (2006) prescribes inoculum incubation to limit methane production from targets

\subsection{Experimental setup and procedure}

Batch digestion tests were carried out in triplicate using $311 \mathrm{ml}$ anaerobic biodigesters with an effective volume of $186 \mathrm{ml}$ at $37^{\circ} \mathrm{C}$. CY manure co-digestion was performed under three substrate/co-substrate ratio: CY-AM (25:75), CY-AM (50:50) and CY-AM (75:25). In addition, two relationships between substrate and inoculum were established: ISR of 1 and ISR of 2. After the inoculum was mixed with the substrate in the biodigesters, the effective volume was completed with distilled water. The amount of added VS of inoculum was the same in all batches. The biodigesters were then hermetically sealed with rubber septa and aluminium plugs. To mix the contents, the biodigesters were shaken with an orbital shaker for 2 min before their start of incubation. As controls, three blank biodigesters containing only inoculum and distilled water were also incubated under the same conditions as the rest of the biodigesters. The biogas yield from these blank biodigesters was used to correct for the biogas produced solely by the inoculum.

\subsection{Biogas measurements and estimation of its composition.}

The volume of biogas produced in each biodigester was calculated daily by measuring the pressure in the headspace of each biodigester using a portable pressure gauge (Delta OHM HD 2124.2). To measure the pressure, a 100-bar pressure sensor (Delta TP 704) was used, which remained connected to the portable pressure gauge. The measurement process consisted of setting up a system, in which three devices were connected: the biodigester, the portable pressure gauge and a syringe for the extraction of the biogas. 
This connection system was carried out with a three-way valve and simultaneously. At the beginning of each extraction, the pressure generated by in the head space of each biodigester was measured. Biogas extraction was completed when the pressure inside the biogas equalized to atmospheric pressure. The biogas volume of each biodigester was calculated through (Equation 1). Finally, the cumulative biogas and methane yields $(\mathrm{ml} / \mathrm{g}$ VS) were calculated by dividing the corrected amount of the cumulative gases (after subtracting the average amount of gas produced from the blank reactors) by the amount of VS used at the beginning of the tests. digestion tests (da Borso et al., 2021; Pearse et al., 2018). Each biodigester was shaken once a day and the volume of biogas was measured once a day.

$$
V_{B I O G A S}(S T P)=\frac{P_{A B S} V_{G} T_{S T P}}{P_{S T P} T_{1}}
$$

where,

$\begin{array}{ll}\text { VBIOGAS }(\mathrm{STP}) & \text { total volume of methane under standard conditions } \\ \mathrm{P}_{\text {ABS }} & \text { absolute pressure generated by overpressure of the digester } \\ \mathrm{T}_{\mathrm{STP}} & \text { temperature in standard conditions }(298 \mathrm{~K}) \\ \mathrm{T}_{1} & \text { experiment test temperature }(311 \mathrm{~K}) \\ \text { PSTP } & \text { pressure under standard conditions }(1 \mathrm{~atm}) \\ \mathrm{V}_{\mathrm{G}} & \text { digester head space volume }(0.124 \mathrm{l})\end{array}$

Biogas composition $\left(\mathrm{CH}_{4}, \mathrm{O}_{2}, \mathrm{CO}_{2}, \mathrm{H}_{2} \mathrm{~S}\right.$ content $)$ was measured using Geotech's BIOGAS GA-5000 meter. In this way, using a $200 \mathrm{ml}$ airtight syringe, biogas samples were taken from the headspace of each biodigester after the gas was released. Before measuring the biogas composition in the headspace, the reactors were stirred for two 
minutes at $100 \mathrm{rev} / \mathrm{min}$. The composition of the biogas was measured once a day until the end of digestion.

\subsection{Characterization of the substrate and inoculum}

The total solids (TS) and volatile solids (VS) of the residues were measured in triplicate according to the UNE-EN 18134 and UNE-EN ISO 18123 standards. While the TS and VS content of the inoculum was determined according to $2540 \mathrm{~A}-2540 \mathrm{G}$ methods of the American Public Health Association (APHA, 2005).. A portable digital multi-meter potentiometer (HACH HQ 40D) was used to determine the $\mathrm{pH}$ of the samples from the biodigesters. Elemental analysis $(\mathrm{C}, \mathrm{H}, \mathrm{N}, \mathrm{O}$ and $\mathrm{S})$ was performed using the VARIO MACRO CUBE elemental analyser.

\subsection{Theoretical BMP}

The methods described below are designed to determine the production of methane from co-digestion from its characterization of the theoretical chemical oxygen demand (CODt), elemental composition or composition of organic fraction. The two methods calculate the theoretical methane potential of all residues under standard conditions (STP) at a temperature of $25^{\circ} \mathrm{C}$ and a pressure of $1 \mathrm{~atm}$.

\section{Methane production from the theoretical chemical oxygen demand $\left(\gamma_{\text {CODt }}\right)$}

Equation 2 allows the maximum methane yield to be calculated from the amount of material and the CODt concentration, assuming its validity for any type of substrate (Nielfa et al., 2015;Liu et al., 2016).

$$
\gamma_{\mathrm{CODt}}\left(\frac{\mathrm{ml} \mathrm{CH}_{4}}{\mathrm{~g} \mathrm{VS}}\right)=\frac{\mathrm{n}_{\mathrm{CH} 4} \cdot \mathrm{RT}}{\text { P.VS }}
$$


where $\gamma_{C O D t}$ is the theoretical production, $R$ is the gas constant $(R=0.082 \mathrm{~atm} 1 / \mathrm{mol} \mathrm{K})$, $\mathrm{T}$ is the temperature of the biodigester $(298 \mathrm{~K}), \mathrm{P}$ is the atmospheric pressure (1atm), VS aggregate $(\mathrm{g})$ are the volatile solids in the substrate and $\mathrm{n}_{\mathrm{CH} 4}$ is the amount of molecular methane (mol).

The value of $\mathrm{n}_{\mathrm{CH}} 4$ has been determined from the CODt (Equation 3) (Maletić et al., 2018). The CODt for methane is $64 \mathrm{~g}$ of oxygen per mole of methane. 1 mole of methane per 64 $\mathrm{g}$ of CODt is, therefore, the maximum amount of methane that can be obtained if all the CODt is converted to methane (Heidrich et al., 2011).

$$
\mathrm{n}_{\mathrm{CH} 4}=\frac{\mathrm{CODt}}{64\left(\frac{\mathrm{g}}{\mathrm{mol}}\right)}
$$

The CODt of all substrates and co-substrates was estimated through their elemental composition and the stoichiometry of the oxidation reaction (Equation 4), using the equation (Equation 5) (Pellera et al., 2016). The calculation of the CODt based on the atomic composition provides an attractive and easy alternative to obtain the organic resistance of some solid substrates (Raposo et al., 2011).

$$
\begin{aligned}
& \mathrm{C}_{\mathrm{a}} \mathrm{H}_{\mathrm{b}} \mathrm{O}_{\mathrm{c}} \mathrm{N}_{\mathrm{d}}+\left(\frac{4 \mathrm{a}+\mathrm{b}-2 \mathrm{c}-3 \mathrm{~d}+2 \mathrm{e}}{4}\right) \mathrm{O}_{2} \\
& \rightarrow \mathrm{aCO}_{2}\left(\frac{\mathrm{b}-3 \mathrm{~d}}{2}\right) \mathrm{CH}_{4}+\mathrm{eH}_{2} \mathrm{O}+\mathrm{dNH}_{3} \\
& \operatorname{CODt}\left(\frac{m l O_{2}}{g V S}\right)=\frac{\left(2 a+\frac{b}{2}-c-\frac{3 d}{2}\right) * 16}{(12 a+b+16 c+14 d)} * 1000
\end{aligned}
$$


Another way to determine the theoretical yield $\left(\gamma_{\text {teo }}\right)$ is through the reaction of (Equation 6), using the Buswell equation (Equation 7). These stoichiometric equations take into account the elemental analysis of the elements of $\mathrm{C}, \mathrm{O}, \mathrm{H}$ and $\mathrm{N}$ of the different substrates and co-substrates(Pellera \& Gidarakos, 2016; Boulanger et al., 2012; Roberts et al., 2016).

$$
\begin{aligned}
\mathrm{C}_{\mathrm{a}} \mathrm{H}_{\mathrm{b}} \mathrm{O}_{\mathrm{c}} \mathrm{N}_{\mathrm{d}}+( & \left.\frac{4 \mathrm{a}-\mathrm{b}-2 \mathrm{c}+3 \mathrm{~d}+2 \mathrm{e}}{4}\right) \mathrm{H}_{2} \mathrm{O} \\
& \rightarrow\left(\frac{4 \mathrm{a}+\mathrm{b}-2 \mathrm{c}-3 \mathrm{~d}-2 \mathrm{c}}{8}\right) \mathrm{CH}_{4}+\left(\frac{4 \mathrm{a}+\mathrm{b}+2 \mathrm{c}+3 \mathrm{~d}+2 \mathrm{e}}{8}\right) \mathrm{CO}_{2} \\
& +\mathrm{dNH}_{3}+\mathrm{eH}_{2} \mathrm{~S} \\
& \gamma_{\text {teo }}\left(\frac{\mathrm{ml} \mathrm{CH}}{\mathrm{g} \mathrm{VS}}\right)=\frac{22400 *(4 a+b-2 c-3 d-2 e)}{(12 \mathrm{a}+\mathrm{b}+16 \mathrm{c}+14 \mathrm{~d}+32 \mathrm{e}) * 8}
\end{aligned}
$$

\subsection{Biodegradability and synergy}

The experimental performance of methane $\left(\gamma_{\exp }\right)$ can be used to calculate anaerobic biological efficiency $(\varepsilon)$ under the defined test conditions compared to its theoretical value $\left(\gamma_{\text {teo}}\right)$, through the (Equation 8) (Shen et al., 2019).

$$
\varepsilon=\frac{\gamma_{(\exp )}}{\gamma_{(\text {teo })}} \cdot 100 \%
$$

Mixing a substrate with one or more substrates, through co-digestion, causes three types of internal reactions of its components:greater production of methane (synergistic effects), less production of methane (antagonistic effects) or simply not increase or decrease production regarding the individual production of a substrate or co-substrate (independence of waste from the coDA). To evaluate the synergy, antagonism and independence that occurs in the biodegradation process, (Equation 9) was used (Nielfa et al., 2015). 


$$
\alpha=\frac{\gamma_{\exp }}{\gamma_{\text {pond }}}
$$

Where $\gamma_{\exp }$ refers to the experimental performance obtained by the BMP. The $\gamma_{\text {pond }}$ corresponds to the weighted experimental performance calculated using (Equation 10) (Castro et al., 2018). If $\alpha>1$, the mixture has synergistic effects. If $\alpha<1$, the mixture had antagonistic effects. If $\alpha=1$, the mixture has independence effects between the substrate and co-substrate.

$$
\gamma_{\text {pond }}=\frac{\gamma_{\mathrm{sp}} \cdot \lambda+\gamma_{\mathrm{cs} \cdot} \beta}{\lambda+\beta}
$$

Where, $\gamma_{s p}$ refers to the methane production obtained from the digestion of the main substrate calculated as monosubstrate. On the other hand, $\gamma_{c s}$ is the production obtained through the singular digestion of the different co-substrates. The values of $\lambda$ and $\beta$ correspond to the VS fractions of the main substrates and the co-substrates.

\subsection{Kinetic Models to Predict BMP}

A mathematical equation can describe the kinetics of the biodegradation process of the substrates. Thus, experimental performance, digestion time and biodegradation kinetics can help predict methane production from a specific substrate (Cecchi et al., 1991). In this work, the methane potential of the co-digested mixtures was predicted using 5 mathematical models applied to the BMP experimental tests. The following models were used: modified Gompertz (Equation 11) (Lay et al., 1997; Zou et al., 2018); Lima et al., 2018; Zwietering et al., 1990; Wang et al., 2021), transfer model (Equation 12) (Li et al., 2012; Ugwu and Enweremadu, 2019), logistic equation (Equation 13) (Deepanraj et al., 
14) (Pitt et al., 1999; Lima et al., 2018; Groot et al., 1996) and modified Richards model

(Equation 15) (Pitt et al., 1999; Ware and Power, 2017).

$$
\begin{gathered}
M=M_{\mathrm{e}} \cdot \exp \left\{-\exp \left[\frac{v_{\mathrm{max}} * e}{M_{\mathrm{e}}}\left(t_{\text {lag }}-\mathrm{t}\right)+1\right]\right\} \\
M=M_{\mathrm{e}}\left\{1-\exp \left[-\frac{v_{\max }}{M_{\mathrm{e}}}\left(t-\mathrm{t}_{\mathrm{lag}}\right)\right]\right\} \\
M=\frac{1+\exp \left[\frac{4 v_{\max }\left(t_{\text {lag }}-t\right)}{M_{\mathrm{e}}}+2\right]}{\mathrm{M}=\frac{M_{\mathrm{e}}}{1+(\mathrm{k} \cdot \mathrm{t})^{-\mathrm{n}}}} \\
\mathrm{M}=\mathrm{M}_{\mathrm{e}}\left\{1+\mathrm{d} \cdot \exp (1) \exp \left[\frac{v_{\max } * \mathrm{e}}{\mathrm{M}_{\mathrm{e}}}(1+\mathrm{d})\left(1+\frac{1}{\mathrm{~d}}\right)\left(\mathrm{t}_{\mathrm{lag}}-1\right)\right]\right\}^{\frac{1}{d}} \\
+1
\end{gathered}
$$

Where $\mathrm{M}$ is the yield of the specific methane accumulated in time $\mathrm{t}\left(\mathrm{mlCH} 4 . \mathrm{g}^{-1} \mathrm{VS}\right), \mathrm{Me}$ is the maximum yield of methane $\left(\mathrm{mlCH}_{4} \cdot \mathrm{g}^{-1} \mathrm{VS}\right)$, $\mathrm{t}$ is the digestion time $(\mathrm{d}), \mathrm{k}$ is the first order decomposition constant $\left(\mathrm{d}^{-1}\right), v_{\max }$ is the maximum specific rate of methane production $\left(\mathrm{mlCH}_{4} \cdot \mathrm{g}^{-1} \mathrm{VS} . \mathrm{d}^{-1}\right)$, tlag is the lethargy or latency time $(\mathrm{d})$, and $\mathrm{n}$ is the shape facto.

\subsection{Statistical analysis}


To compare the effect of the inoculum and the effect of codigestion of the different AD groups, the differences in the experimental data between the results obtained were evaluated by means of the one-way analysis of variance (ANOVA). The results were considered significant only if the $\mathrm{p}$ value was less than 0.05 (ie, $\mathrm{p}<0.05$ ). In addition, to determine the degree of fit between the experimental and predicted values, the mean absolute error MAE, the coefficient of determination $\left(\mathrm{r}^{2}\right)$ and the root mean square error (RMSE) were used. Through these statistical parameters, it was determined which is the model that best predicts the kinetics of the raw materials evaluated. All calculations were performed with the STATISTICA 10 statistical package.

\section{Results}

\subsection{Characterization of the physicochemical properties of the raw material}

The results of the analysis of the physicochemical characteristics of the substrate, cosubstrate and inoculum are presented in Table 1. The TS and VS content of the CY were $33.9 \%$ and $24.6 \%$ respectively. These results were lower than the TS and VS content of other studies reported in the literature, where they varied between $68.51 \%$ and $27.82 \%$ respectively (Garfí et al., 2011). Variations in the composition of TS and VS can be attributed to possible changes in the nutrition and age of the animals, as well as changes in manure management, storage conditions, and sampling time (Masse et al., 2003).

All lignocellulosic residues used as a co-substrate presented high percentages of VS and TS. Also, the TR residuals were characterized by having the highest values of TS $(92.6 \%)$, VS (71.5\%) and VS/TS (0.77). However, these results were lower than those obtained by Sun et al. (2019), who obtained TS, VS and VS/TS values of 74.1\%; $62.9 \%$ and 0.84 respectively. The co-substrate of AM presented similar characteristics of VS (88.2\%), TS $(65.9 \%)$ and VS/TS (0.75) to those of TR. Furthermore, the AM results were superior to 
those obtained by Seppälä et al. (2013), who reported TS and VS values of $18.0 \%$ and $14.4 \%$ respectively. Finally, the QU co-substrate presented a high value of TS $(87.0 \%)$ and low values of VS (50.8\%) and VS/TS (0.58). Thus, the results of TS, VS and VS/TS of QU were lower than those obtained by Alvarez \& Lidén (2008), who obtained values of $95.3 \% ; 91.9 \%$ and 0.88 respectively.

Finally, the inoculum (IN) presented TS of $3.9 \%$; VS of $2.3 \%$ and a VS/TS ratio of 0.59 . The IN values were similar to those used by Sun et al. (2019), who reported TS, VS and VS/TS of $5.9 \% ; 3.19 \%$ and 0.58 . Likewise, the IN results were comparable to those of Pellera \& Gidarakos (2016), who reported TS, VS and VS/TS of 2.7\%; $1.7 \%$ and 0.62 respectively.

\subsection{Effects of inoculum on biogas production}

The daily methane production rates of the different mixtures are presented under two substrate-inoculum ratios (ISR of 1 and ISR of 2) (Figure 1). In both proportions, the methanogenic activity began immediately shortly after the start of the incubation, causing a rapid adaptability of the microorganisms to occur. Furthermore, regardless of the ISR, it is observed that the methane curves showed a similar pattern, with a higher production in the first days. At the ISR of 1 and ISR of 2, the maximum methane rates were 32.33 $\mathrm{ml} \mathrm{CH}_{4} / \mathrm{g}$ VS and $32.39 \mathrm{mlCH}_{4} / \mathrm{g} \mathrm{VS}$, respectively. With the increase in the amount of inoculum from 50 to $66.7 \%$, the daily productions decreased slightly. However, in both proportions the highest methane peaks occurred in the mixtures of CY-AM and CY-QU.

For the ISR of 1, more than half of the total methane produced was obtained during the first 10 days. During this period, production varied between 62 and $76 \%$. Between days 11 and 20, methane productions varied between 13 and 24\%. On the other hand, in the interval between days 21 and 30, methane production decreased by 5 to $10 \%$ percentages. 
Finally, in the interval of days 31 and 40 the digesters produced very low amounts of methane of 1 to $8 \%$. When the amount of inoculum was increased, that is, when it went from an ISR of 1 to an ISR of 2, the material in the digesters digested faster which caused the accumulated methane production to increase. Thus, in the first 10 days, percentages of 54 to $67 \%$ were obtained. In the interval from day 11 to day 20 , production percentages of 17 to $31 \%$ were obtained. Between days 21 and 30, it decreased dramatically to percentages of 8 to $14 \%$. Finally, in the last stage of co-digestion (31-40), methane production decreased to percentages of 1 to $7 \%$.

The maximum accumulated methane production was obtained after $960 \mathrm{~h}$ of digestion (40 days) when the daily methane productions were $1 \%$ of the total accumulated production (Zhao et al., 2019). The results showed that an increase in the amount of inoculum contributed to the samples increasing their methane production. When comparing the methane production of the ISR of 1 with the ISR of 2 , all the trials showed significant differences $(\mathrm{P}>0.05)$ according to the Tukey test; Except for the CY-QU (50:50) mixture that did not present significant figures $(\mathrm{P}<0.05)$. The increase in the improvement of the methane rate of the ISR of 2 compared to the ISR of 1 was around 9 and $31 \%$. These results suggested that a high ISR $>1$ ratio favour methane production in manure codigestion of CY with residues of AM, QU and TR.

\subsection{Effect of lignocellulosic residues on co-digestion}

Several studies have shown that methane production from animal manure can be improved by co-digestion with a variety of co-substrates of agricultural origin (Shrestha et al., 2017). However, the increase in methane production depends on the proper ratio between the main substrate and the co-substrate. In this study, the mixtures that generated the highest methane rate were those with the highest concentration of co-substrate (AM, QU and TR). Thus, all tests with $75 \%$ co-substrate significantly improved compared to 
those mixtures with 25 and $50 \%$ co-substrate. The highest amount of methane was obtained in the mixtures of CY-AM (25:75), CY AM (50:50), CY-QU (25:75), CY-QU (50:50) and CY-TR (25:75) with 341.86; 333.91; 341.05; 315.24 and $315.92 \mathrm{ml} / \mathrm{g} \mathrm{VS}$, respectively. However, the results revealed that when using $75 \%$ or $50 \%$ of co-substrate in the mixtures, the methane production rates did not present significant figures $(\mathrm{P}<0.05)$. In addition, it was found that by increasing the amount of co-substrate from $25 \%$ to $75 \%$, the mixtures increased their methane production between 20 and 26\%. Likewise, when the amount of co-substrate was increased from 25 to $50 \%$, methane production in the biodigesters improved between 16 and $20 \%$. It was also found that all lignocellulosic residues used were good co-substrates to improve the digestion of CY manure. This is justified, since all the tests with a 50 and $75 \%$ concentration of co-substrate did not present significant figures $(\mathrm{P}<0.05)$ in methane generation.

\section{Synergistic effects of anaerobic co-digestion}

In Figure 2, the results of the methane production and the synergy of the mono-digestion and co-digestion of the manure residues of $\mathrm{CY}$ and the agricultural residues of $\mathrm{AM}, \mathrm{QU}$ and TR are presented. The mono-digestion data incorporated in this article has already been calculated in another article (Meneses et al., 2021) in which the same methodology of this research has been followed. This allows the individual performance of CY manure to be compared with the performance of substrate and co-substrate mixtures.

The value of the synergistic effect $(\alpha)$ in the mono-digestion of the manure of CY and the agricultural residues of AM, QU and TR was assumed as 1, since the values of $\alpha$ have been estimated from the mixing proportions and the individual yields. of the substrate and co-substrate. The manure mono-digestion methane yields of CY (ISR of 1) and CY (ISR of 2) were 211.07 and $174.27 \mathrm{ml} / \mathrm{g}$ VS, respectively. The co-digestion mixtures improved the methane production of the mono-digestion regardless of the ISR used. The increments 
of improvement ranged from 8 to $42 \%$ for the ISR of 1 and between 50 and $96 \%$ for the ISR of 2. All comparisons between mono-digestion and co-digestion data showed significant differences $(\mathrm{P}>0.05)$, Except for the CY-TR (25:75) mixture of the ISR of 1 that did not present significant differences $(\mathrm{P}<0.05)$.

Figure 2 shows that the values of $\alpha$, of the ISR of 1 , for the mixtures of CY-AM $(75: 25)$, CY-QU (75:25), CY-TR (50:50) and CY-TR (75:25) ranged from 0.957 to 0.988 , which suggests that the co-digestion of these mixtures is independent of the substrate and cosubstrates used since the value of $\alpha$ was close to 1 . However, the mixtures of CY-AM and CY -QU, with a content of 50 and $75 \%$ of co-substrate, had synergistic effects $(\alpha>1)$ with values that ranged between 1.11 and 1.17. In the ISR of 2, the synergistic effects were much more promising since their values ranged between 1.13 and 1.50 ; except for the CY-QU (25:75) mixture where $\alpha$ was 0.975 . In which case in this last mixture there were no synergistic effects, but neither were completely antagonistic effects, since $\alpha$ was close to 1 .

The mixtures with high content of AM, QU and TR showed stronger synergistic effects regardless of the ISR used. These results are consistent with methane yields, suggesting that a high proportion of co-substrates added to the CY manure digestion could have positive effects on the co-digestion yield.

\subsection{Biogas composition of CY waste}

In Figure 3, the biogas composition of the different combinations between cosubstrates and inoculum is shown. The results showed that the percentages of $\mathrm{CH}_{4}$ and $\mathrm{H}_{2} \mathrm{~S}$ increased with the increase of inoculum; on the contrary, the generation of $\mathrm{CO}_{2}$ decreased as the amount of inoculum increased. The mixtures composed of CY-QU were the ones that generated the highest percentage of methane regardless of the ISR used. In the trials with 
an ISR of 2, the mixtures formed by CY-QU experienced improvements of 2.26-4.52\% compared to the combinations of CY-AM and improvements of $2.68-5.68 \%$ compared to the biodigesters formed by CY-TR. In the same way, the biodigesters formed by CY-QU of the ISR of 1 , generated higher percentages of $\mathrm{CH}_{4}$. These differences were 9.89$10.58 \%$ and $12-84-14.59 \%$ with respect to the biodigesters formed by CY-AM and CYTR, respectively.

In this study, $\mathrm{CO}_{2}$ was between $29-42 \%, \mathrm{H}_{2} \mathrm{~S}$ was almost negligible with percentages of $0.40-1.70 \%$, on the contrary, the percentage of $\mathrm{CH}_{4}$ was around 57-69\%. The results obtained were similar to those of other investigations in the literature. Thus, for example, Garfí et al. (2011) in a study on the AD of guinea pig manure, obtained values of $63-65 \%$ for $\mathrm{CH}_{4}$, and values of $0.19 \%$ for $\mathrm{H}_{2} \mathrm{~S}$. Similarly, in another study on guinea pig manure, Garfí et al. (2011) obtained percentages of $59 \%$ and $0.15 \%$ for $\mathrm{CH}_{4}$ and $\mathrm{H}_{2} \mathrm{~S}$, respectively. Also, Ferrer. (2011), recorded values of $60 \%$ of the methane fraction in previous biomethanization studies.

\subsection{Kinetic study}

\section{Estimation of kinetic parameters}

The kinetic modelling parameters were calculated using the Richards, logistic, modified Gompertz equations and the Cone model presented in Table 2.

When analysing the $v_{\max }$ parameter, it is verified that the modified Gompertz models and the logistic equation are the ones that correlate the most and have the most similarity, since their $\nu_{\max }$ values are between 11.98-20.80 $\mathrm{mlCH}_{4} / \mathrm{g}$ VS $\mathrm{d}$ and between 10.69-19.52 $\mathrm{mlCH}_{4} / \mathrm{g}$ VS d, respectively. On the other hand, the methanogenic activity occurred at a faster rate in the transfer model, since, for this model, $v_{\max }$ ranged between 21.86 and $31.31 \mathrm{mlCH}_{4} / \mathrm{g} \mathrm{VS} \mathrm{d}$. The model that differs the most from the rest of the models is that 
of Richards, where the range of $\nu_{\max }$ was between 2.13 and $13.76 \mathrm{mlCH}_{4} / \mathrm{g} \mathrm{VS} \mathrm{d}$. In contrast, with other investigations, the $v_{\max }$ values of this study are lower than those reported for food residues (28.03 to $174.63 \mathrm{mlCH}_{4} / \mathrm{g} \mathrm{VS} \mathrm{d}$ ) (Li et al., 2018) and those reported for manure chicken (19.4 to $48.9 \mathrm{mlCH}_{4} / \mathrm{g} \mathrm{VS} \mathrm{d}$ ) (Li et al., 2013). However, the $v_{\max }$ results of this study are similar to those reported for corn stubble (16.3 to 32.1 $\mathrm{mlCH}_{4} / \mathrm{g} \mathrm{VS} \mathrm{d}$ ) (Li et al., 2013) and higher than those of manure co-digestion of pig with sewage sludge (4.8-14.0 $\mathrm{mlCH}_{4} / \mathrm{g}$ VS d) (Zhang et al., 2014).

Regarding the specific experimental methane yield, the results of the ISR of 2 are those that best fit the kinetic parameter $\mathrm{M}_{\mathrm{e}}$. Thus, the mean difference between the observed and predicted values are around 0.16-5.53\% (modified Gompertz), 1.04-8.30\% (transfer), 2.40-7.04\% (equation logistics) and between $0.32-5.32 \%$ (Richards). These trends suggest that these models are suitable for representing the variables of the digestion process and estimating the AD yield and kinetic parameters. On the other hand, in the cone model, the differences between the predicted and observed values were more overestimated since they ranged between 5.85-18.95\%. The fact that there are discrepancies in the mean differences between the experimental performance and the predicted ones is due to the types of kinetic models used, raw material, conditions used and the digestion of more complex residues (co-digestion). However, the average differences obtained between specific performance and $M_{e}$ were in line with those obtained by Ware and Power (2017), who obtained differences of 0.54 and $27.07 \%$.

Regarding the latency period ( $\left.\mathrm{t}_{\mathrm{lag}}\right)$, many of the digesters experienced very short periods, even 0 days, which indicates the high bioavailability of organic compounds within the substrates (Ware and Power, 2017). In this sense, CY co-digestion experienced zero periods in its latency phase, except for CY-AM digesters (25:75), whose maximum periods were around 0.41 days (modified Gompertz); 0.98 days (transfer); 0.71 days 
(logistics) and 0.42 days (Richards). The fact that there are low latency periods in these trials indicates that there was a rapid response of the microorganisms in their process of adaptation to the environment and conditions of the experiment. Furthermore, the low tlag values demonstrated the simple nature of the substrates and co-substrates, and their high biodegradability. Finally, it is important to note that, compared to other authors who previously reported latency periods of 0.50 days (Zhang et al., 2017) and 12.3 days (Fang et al., 2014), the tlag of some biodigesters of this study were relatively similar and even shorter.

\section{Evaluation and comparison of the different kinetic models}

According to Figure 4, the kinetic model that has the highest correlation coefficient $\mathrm{r}^{2}$ (0.992-0.999) and the lowest RMSE (1.37-10.04 $\mathrm{mlCH}_{4} / \mathrm{g}$ VS) is the transfer model. Similarly, the cone model fit the data quite well with an $r^{2}(0.978-0.999)$ and an RMSE of (1.16-8.85 $\left.\mathrm{mlCH}_{4} / \mathrm{g} \mathrm{VS}\right)$. While the model of the logistic equation is the one that best adjusts the values observed with the models, since the value of $r^{2}$ and the RMSE range between (0.974-0.997) and (3.58-14.30 $\mathrm{mlCH}_{4} / \mathrm{g}$ VS) respectively. On the other hand, the modified Gompertz and Richards models have a lot of similarity yes. Thus, in the modified Gompertz model the correlation coefficient is in an interval of (0.965 0.999) and the RMSE in an interval of (2.16-11.31 $\mathrm{mlCH}_{4} / \mathrm{g}$ VS); while in the Richards model $\mathrm{r}^{2}$ is between (0.982-0.999) and RMSE between (2.16-11.33 $\left.\mathrm{mlCH}_{4} / \mathrm{g} \mathrm{VS}\right)$. This similarity between these two models is due to the fact that the Richards model tends to transform into the modified Gompertz model, since its parameter "d" tends to reduce to 0 . Furthermore, the sigmoidal models (modified Gompertz, logistic equation and Richards) (Altaş, 2009), when they described the sigmoidal growth of the curves, they had a higher RMSE. 
On the other hand, in the transfer model there was not a total convergence between the observed and predicted values when the non-linear regression was performed. The fact that there was no convergence for the entire duration of co-digestion meant that there were no predicted values in all the biodigesters tested. In this sense, this model did not provide all the information necessary for its correct evaluation and evaluation of the data.

It should be noted that the suitability and precision of the models always vary considerably depending on the experimental conditions, the operating parameters, as well as the origin of the inoculum and the type of substrate used (Zhen et al., 2015). In this study, of all the proposed models, the cone model best adjusted to the real evolution of methane production. Similarly, El-Mashad (2013) demonstrated the cone model makes a better realistic simulation of experimental methane yields. The fact that the cone model is the most suitable for making the best predictions on methane production is very interesting since many studies have traditionally considered the Gompertz model to be the most suitable (Zhen et al., 2014; Lu et al., 2014; Kacprzak, Krzystek et al., 2012). On the contrary, other authors (Pitt et al., 1999) have considered that the cone model does not adequately model the results of methane production. The low credibility in the cone model, despite its high precision, may be due to the little familiarity of many authors with this model (Zhen et al., 2015).

\section{Discussion}

\subsection{Effect of ISR on biomethane potential and biodigester stability}

In the current study, the results showed that methane yields increased at a higher ISR, and are in agreement with previous studies in which different substrates have been used (Silva et al., 2020; Córdoba et al., 2018; Raposo et al., 2009; Wei et al., 2014). An optimal ISR in the biodigester is considered to contain the balanced amount of anaerobic 
microorganisms for the digestion of primary and intermediate products (Eskicioglu and Ghorbani, 2011). Furthermore, an adequate inoculum can increase the degradation rate, improve biogas production, shorten the start-up time, and make the digestion process more stable (Quintero et al., 2012). However, determining the optimal values of an ISR is not easy, especially when the substrates and co-substrates used are relatively unknown. Raposo et al. (2006) in a BMP test of corn waste used an ISR range of 3, 2, 1.5 and 1 and concluded that their results presented a slight variation in higher proportions. Caillet et al. (2019) in a sugarcane distillery wastewater biomethanization test determined that the methane production rate with an ISR of 1 was faster and higher than in the proportions of 2; 2.6 and 3.9. The use of a high or low ISR can be decisive in BMP tests. While a very high ISR will primarily challenge the experimental setup due to the relatively low gas production of the substrate (Caillet et al., 2019), a low ISR could cause an overload of the microbial community, as has already been shown in several studies. previous (Polizzi et al., 2017; Holliger et al., 2016). From the literature consulted, it can be concluded that methane production rates are specific to the substrate and the inoculum, so it is not always possible to make general statements about the performance of digestion.

In this study, the use of an ISR of 2 notably improved the biodegradability of the materials compared to an ISR of 1 . Despite all this, more trials with different ISR proportions (greater than 2) are needed to fully evaluate the influence of the inoculum; especially since the co-digestion tests were carried out from easily degradable material (CY manure) and lignocellulosic material. In addition, the materials used are little known which means that there is little literature evaluating their energy potential.

\subsection{Effect of co-digestion on biomethane potential and process stability}


Co-digestion of CY manure with lignocellulosic residues, in general, constantly increased methane production. Co-digestion was very productive, despite the fact that traditionally, throughout the world, animal manure has been used as a mono-substrate in most biomethanization tests (Wu et al., 2010). In this case, due to the inherent carbon deficiency in manure and the increase in the synergistic effects of co-digestion by AM, QU and TR, the biodegradability in the biodigester was increased (Himanshu et al., 2018; Khoufi et al., 2015). The results obtained in this study were very similar to those of other authors and were corroborated with previous studies (Table 3). The best results ranged from 300-340 $\mathrm{CH}_{4} / \mathrm{g}$ VS, which means that they correspond to an average methane production. According to Velázquez et al. (2018), the low methane productions range between 150 and $300 \mathrm{CH}_{4} / \mathrm{g}$ VS, the average productions between 300 and $450 \mathrm{CH}_{4} / \mathrm{g} \mathrm{VS}$ and the high productions are higher than $450 \mathrm{CH}_{4} / \mathrm{g}$ VS.

CY manure mono-digestion production was low (around 170-211 $\mathrm{CH}_{4} / \mathrm{g}$ VS) compared to previous studies of cow, pig, and poultry manure that ranged from 238,271 , and 328 $\mathrm{ml} / \mathrm{g}$ VS, respectively (Meneses \& Velázquez, 2020).The low production of methane can be attributed to the quality and management techniques of the organic matter in manure (Ferrer et al., 2011). In rural Andean areas, harsh climatic conditions and frost-tolerant forages give an animal diet quite different from that of other climates and conditions (Alvarez and Lidén, 2009). The type of diet of the animal can influence so that the content of the CY manure has a lower content of proteins and lipids, and a greater amount of difficult to digest material (Alvarez \& Lidén, 2006).

The proportions that generated the best results were those in which 50 and $75 \%$ of the cosubstrate was used (based on VS content). Concentrations of $25 \%$ generated lower ranges of methane (260-276 ml/g VS). Low efficiencies can be attributed to a higher content of lignin or other recalcitrant carbon in the composition of the biodigester (Ebner et al., 
2016). Ma et al. (2020), concluded that for a maximum improvement of the methane yield of pig manure and cow manure, the recommended proportions of lignocellulosic residues should be approximately 30-50\%. By contrast, co-substrate concentrations between 60 and $90 \%$ can produce low methane yields in co-digestion. However, the variations in cosubstrates in co-digestion have very wide ranges and depend on the type of manure used (Vivekanand et al., 2018). Determining the appropriate ratio between substrate and cosubstrate is essential to optimize the co-digestion processes (Jeung et al., 2019); above all because the proportions of the co-substrates, in the co-digestions, vary greatly between different studies (Andriamanohiarisoamanana et al., 2018; Zahan et al., 2018).

The synergistic effects were closely related to methane production; therefore, the biodigesters with a greater amount of co-substrate had a greater synergistic effect and greater yield. The biochemical potential of methane as well as the synergy are directly related to the composition of the substrate (Astals et al., 2014). The composition of the substrate determines the efficacy of the microbial population, which in turn greatly influences biogas yield, long-term process stability, and solids degradation rate (Castro et al., 2018). On the other hand, the presence of antagonistic effects in some biodigesters (CY-TR (75:25; CY-QU (75:25)) is due to the fact that in this study the co-digestion of binary mixtures was carried out, since when there are mixtures of three and four substrates, greater synergy effects are achieved than in mixtures of two substrates (Baquerizo et al., 2016). Finally, in biodigesters that present antagonism, binary mixtures have not been able to provide all the nutrients and trace elements necessary to that microorganisms have a higher methanogenic activity (Pagés et al., 2014).

Anaerobic digestion (AD) of animal manure and lignocellulosic residues is gaining greater interest as a result of its wide availability, optimal physicochemical 
characteristics, high methane potential, and absence of conflict with the human food chain compared to energy crops (Naik et al., 2010).

\section{Conclusions}

This study evaluated methane production by anaerobic codigestion of guinea pig manure from amaranth (AM), quinoa (QU) and wheat (TR) cosubstrates. In addition, the effect of an inoculum from sewage sludge on the biochemical potential of methane was investigated. A substrate-to-inoculum ratio (ISR) of 2 was shown to be more suitable for manure codigestion of CY. Specifically, an ISR of 2 resulted in methane yields of 341.86 $\mathrm{ml} \mathrm{CH}_{4} / \mathrm{g}$ VS for the CY:AM biodigester (25:75). The influence of the co-substrates was notable in methane production, since improvements between 20 and $26 \%$ were obtained when the co-substrate concentration was increased from 25 to $75 \%$. Finally, the results of the kinetic modeling concluded that the transfer and cone models are the most suitable to simulate the cumulative biogas and methane production curve, since they provided an $\mathrm{r}^{2}$ of 0.999 . However, in the transfer model, not all the data converged between the observed and estimated values, especially in the CY-AM (50:50) and CY-QU (50:50) biodigesters.

Author Contributions: "Conceptualization, B. Velázquez-Martí and O.W. MenesesQuelal; methodology, B. Velázquez-Martí, O.W. Meneses-Quelal, Z. Niño-Ruiz; validation, B. Velázquez-Martí, Z. Niño-Ruiz; formal analysis, B. Velázquez-Martí, O.W. Meneses-Quelal, J. Gaibor-Chávez; investigation, writing-original draft preparation, B. Velázquez-Martí, O.W. Meneses-Quelal; writing review and editing, B. Velázquez-Martí, Z. Niño-Ruiz, A. Ferrer-Gisbert; funding acquisition, B. VelázquezMartí, Z. Niño-Ruiz, J. Gaibor-Chávez. 
Acknowledgments: This work has been carried out within the framework of the project "Analysis of the implementation of biomass exploitation chains in rural communities in the province of Bolívar (Ecuador)" of the ADSIEO-COOPERATION program of the Polytechnic University of Valencia (UPV). The Ecuadorian Energy Exploitation Research Network of Biomass (ECUMASA) and the IBEROMASA Network of the Ibero-American Program of Science and Technology 517 for Development (CYTED) have participated in this program.

Availability of data and materials. The datasets during the current study are available from the corresponding author on reasonable request.

Funding. This work has been carried out within the framework of the project "Analysis of the implementation of biomass exploitation chains in rural communities in the province of Bolívar (Ecuador)" of the ADSIEO-COOPERATION program of the Polytechnic University of Valencia (UPV). The Ecuadorian Energy Exploitation Research Network of Biomass (ECUMASA) and the IBEROMASA Network of the Ibero-American Program of Science and Technology 517 for Development (CYTED) have participated in this program.

\section{Compliance with ethical standards}

Ethical approval Not applicable.

Consent to participate Not applicable.

Consent to publish Not applicable. 
Conflicts of Interest: "The authors declare no conflict of interest."

\section{REFERENCES}

Altaş, L., 2009. Inhibitory effect of heavy metals on methane-producing anaerobic granular sludge. J. Hazard. Mater. 162, 1551-1556. https://doi.org/10.1016/j.jhazmat.2008.06.048

Alvarez, R., Lidén, G., 2009. Low temperature anaerobic digestion of mixtures of llama, cow and sheep manure for improved methane production. Biomass and Bioenergy 33, $527-533$.

\section{https://doi.org/10.1016/j.biombioe.2008.08.012}

Alvarez, R., Lidén, G., 2008. Anaerobic co-digestion of aquatic flora and quinoa with manures from Bolivian Altiplano. Waste Manag. 28, 1933-1940. https://doi.org/10.1016/j.wasman.2007.11.002

Alvarez, R., Villca, S., Lidén, G., 2006. Biogas production from llama and cow manure at high altitude. Biomass and Bioenergy 30, 66-75. https://doi.org/10.1016/j.biombioe.2005.10.001

Andriamanohiarisoamanana, F.J., Saikawa, A., Kan, T., Qi, G., Pan, Z., Yamashiro, T., Iwasaki, M., Ihara, I., Nishida, T., Umetsu, K., 2018. Semi-continuous anaerobic codigestion of dairy manure, meat and bone meal and crude glycerol: Process performance and digestate valorization. Renew. Energy 128, 1-8. https://doi.org/10.1016/j.renene.2018.05.056

Astals, S., Batstone, D.J., Mata-Alvarez, J., Jensen, P.D., 2014. Identification of synergistic impacts during anaerobic co-digestion of organic wastes. Bioresour. Technol. $169,421-427$.

\section{https://doi.org/10.1016/j.biortech.2014.07.024}

Azevedo-Ramos, C., Moutinho, P., 2018. No man's land in the Brazilian Amazon: Could undesignated public forests slow Amazon deforestation? Land use policy 73, 125-127. https://doi.org/10.1016/j.landusepol.2018.01.005 
Baquerizo Crespo, R.J., Díaz, J., Pereda Reyes, I., 2016. El modelo de Buswell. Aplicación y comparación. Principales factores que influyen en su aplicación. Virtual Pro.

Barreros Chiluisa, E.I., 2017. Efecto de la relación carbono/nitrógeno en el tiempo de descomposición del abono de cuy (Cavia porcellus), enriquecido.

Boronat Gil, M.I., 2013. Propuesta de un matadero de alpacas y planta de elaboración de charqui mediante el uso de las tecnologías apropiadas para el distrito de Cotaruse (departamento de Apurimac, Perú).

Bortolini, J., Tavares, M.H.F., Freitag, D.T., Kuczman, O., 2020. Removal of solids and chemical oxygen demand in poultry litter anaerobic digestion with different inocula. Rev. Ambient. Água 15.

Boulanger, A., Pinet, E., Bouix, M., Bouchez, T., Mansour, A.A., 2012. Effect of inoculum to substrate ratio (I/S) on municipal solid waste anaerobic degradation kinetics and potential. Waste Manag. 32, 2258-2265.

Caillet, H., Lebon, E., Akinlabi, E., Madyira, D., Adelard, L., 2019. Influence of inoculum to substrate ratio on methane production in Biochemical Methane Potential (BMP) tests of sugarcane distillery waste water. Procedia Manuf. 35, 259-264. https://doi.org/10.1016/j.promfg.2019.05.037

Castro-Molano, L. del P., Escalante-Hernández, H., Lambis-Benítez, L.E., Marín-Batista, J.D., 2018. Synergistic effects in anaerobic codigestion of chicken manure with industrial wastes . DYNA.

Cecchi, F., Mata-Alvarez, J., Marcomini, A., Pavan, P., 1991. First order and stepdiffusional kinetic models in simulating the mesophilic anaerobic digestion of complex substrates. Bioresour. Technol. 36, 261-269. 
Cedano-Castro, J.I., Jiménez, R., Huamán, A., Fuerst-Waltl, B., Wurzinger, M., Gutiérrez, G., 2020. Estimation of genetic parameters for four Peruvian guinea pig lines. Trop. Anim. Health Prod. 53, 34. https://doi.org/10.1007/s11250-020-02473-6

Chen, Y., Zhu, R., Jiang, Q., Sun, T., Li, M., Shi, J., Chai, H., Gu, L., Ai, H., He, Q., 2019. Effects of green waste participation on the co-digestion of residual sludge and kitchen waste: A preliminary study. Sci. Total Environ. 671, 838-849. https://doi.org/10.1016/j.scitotenv.2019.03.339

Córdoba, V., Fernández, M., Santalla, E., 2018. The effect of substrate/inoculum ratio on the kinetics of methane production in swine wastewater anaerobic digestion. Environ. Sci. Pollut. Res. 25, 21308-21317. https://doi.org/10.1007/s11356-017-0039-6

da Borso, F., Chiumenti, A., Fait, G., Mainardis, M., Goi, D., 2021. Biomethane Potential of Sludges from a Brackish Water Fish Hatchery. Appl. Sci. . https://doi.org/10.3390/app11020552

Deepanraj, B., Sivasubramanian, V., Jayaraj, S., 2015. Experimental and kinetic study on anaerobic digestion of food waste: The effect of total solids and $\mathrm{pH}$. J. Renew. Sustain. Energy 7, 63104. https://doi.org/10.1063/1.4935559

Ebner, J.H., Labatut, R.A., Lodge, J.S., Williamson, A.A., Trabold, T.A., 2016. Anaerobic co-digestion of commercial food waste and dairy manure: Characterizing biochemical parameters and synergistic effects. Waste Manag. 52, 286-294. https://doi.org/10.1016/j.wasman.2016.03.046

El-Mashad, H.M., 2013. Kinetics of methane production from the codigestion of switchgrass and Spirulina platensis algae. Bioresour. Technol. 132, 305-312. https://doi.org/10.1016/j.biortech.2012.12.183

Eskicioglu, C., Ghorbani, M., 2011. Effect of inoculum/substrate ratio on mesophilic anaerobic digestion of bioethanol plant whole stillage in batch mode. Process Biochem. $46,1682-1687$.

https://doi.org/https://doi.org/10.1016/j.procbio.2011.04.013 
Fang, M., Wu, S., Zhang, W., Li, W., Pang, C., Dong, R., 2014. Influence of inoculumsubstrate ratio on food waste mesothermal anaerobic digestion. J. China Agric. Univ. 19, 186-192.

Federation, W.E., Association, A.P.H., 2005. Standard methods for the examination of water and wastewater. Am. Public Heal. Assoc. Washington, DC, USA.

Ferrer, I., Garfí, M., Uggetti, E., Ferrer-Martí, L., Calderon, A., Velo, E., 2011. Biogas production in low-cost household digesters at the Peruvian Andes. Biomass and Bioenergy 35, 1668-1674. https://doi.org/10.1016/j.biombioe.2010.12.036

García, M.E., 2019. Death of a Guinea Pig: Grief and the Limits of Multispecies Ethnography in Peru. Environ. Humanit. 11, 351-372. https://doi.org/10.1215/22011919$\underline{7754512}$

Garfí, M., Castro, L., Montero, N., Escalante, H., Ferrer, I., 2019. Evaluating environmental benefits of low-cost biogas digesters in small-scale farms in Colombia: A life cycle assessment. Bioresour. Technol. 274, 541-548. hhttps://doi.org/10.1016/j.biortech.2018.12.007

Garfí, M., Ferrer-Martí, L., Perez, I., Flotats, X., Ferrer, I., 2011a. Codigestion of cow and guinea pig manure in low-cost tubular digesters at high altitude. Ecol. Eng. 37, 20662070.

\section{https://doi.org/10.1016/j.ecoleng.2011.08.018}

Garfí, M., Ferrer-Martí, L., Villegas, V., Ferrer, I., 2011b. Psychrophilic anaerobic digestion of guinea pig manure in low-cost tubular digesters at high altitude. Bioresour. Technol. 102, 6356-6359. https://doi.org/10.1016/j.biortech.2011.03.004

Garfí, M., Martí-Herrero, J., Garwood, A., Ferrer, I., 2016. Household anaerobic digesters for biogas production in Latin America: A review. Renew. Sustain. Energy Rev. 60, 599614. https://doi.org/10.1016/j.rser.2016.01.071 
Gómez-Quiroga, X., Aboudi, K., Álvarez-Gallego, C.J., Romero-García, L.I., 2019. Enhancement of Methane Production in Thermophilic Anaerobic Co-Digestion of Exhausted Sugar Beet Pulp and Pig Manure. Appl. Sci. . https://doi.org/10.3390/app9091791

Góngora, J.C., 2003. Beneficios y costos de políticas públicas ambientales en la gestión de residuos sólidos: Chile y países seleccionados. United Nations Publications.

Gonzalez-Salazar, M.A., Morini, M., Pinelli, M., Spina, P.R., Venturini, M., Finkenrath, M., Poganietz, W.-R., 2014. Methodology for estimating biomass energy potential and its application to Colombia. Appl. Energy 136, 781-796. https://doi.org/10.1016/j.apenergy.2014.07.004

Groot, J.C.J., Cone, J.W., Williams, B.A., Debersaques, F.M.A., Lantinga, E.A., 1996. Multiphasic analysis of gas production kinetics for in vitro fermentation of ruminant feeds. Anim. Feed Sci. Technol. 64, 77-89. https://doi.org/10.1016/S0377$\underline{8401(96) 01012-7}$

He, K., Lei, Y., Pan, X., Zhang, Y., Zhang, Q., Chen, D., 2010. Co-benefits from energy policies in China. Energy 35, 4265-4272. https://doi.org/https://doi.org/10.1016/j.energy.2008.07.021

Heidrich, E.S., Curtis, T.P., Dolfing, J., 2011. Determination of the Internal Chemical Energy of Wastewater. Environ. Sci. Technol. 45, 827-832. https://doi.org/10.1021/es103058w

Himanshu, H., Murphy, J.D., Grant, J., O’Kiely, P., 2018. Antagonistic effects on biogas and methane output when co-digesting cattle and pig slurries with grass silage in in vitro batch anaerobic digestion. Biomass and Bioenergy 109, 190-198. https://doi.org/https://doi.org/10.1016/j.biombioe.2017.12.027

Holliger, C., Alves, M., Andrade, D., Angelidaki, I., Astals, S., Baier, U., Bougrier, C., Buffière, P., Carballa, M., De Wilde, V., 2016a. Towards a standardization of biomethane potential tests. Water Sci. Technol. 74, 2515-2522. 
Holliger, C., Alves, M., Andrade, D., Angelidaki, I., Astals, S., Baier, U., Bougrier, C., Buffière, P., Carballa, M., De Wilde, V., Ebertseder, F., Fernández, B., Ficara, E., Fotidis, I., Frigon, J.C., De Laclos, H.F., Ghasimi, D.S.M., Hack, G., Hartel, M., Heerenklage, J., Horvath, I.S., Jenicek, P., Koch, K., Krautwald, J., Lizasoain, J., Liu, J., Mosberger, L., Nistor, M., Oechsner, H., Oliveira, J.V., Paterson, M., Pauss, A., Pommier, S., Porqueddu, I., Raposo, F., Ribeiro, T., Pfund, F.R., Strömberg, S., Torrijos, M., Van Eekert, M., Van Lier, J., Wedwitschka, H., Wierinck, I., 2016b. Towards a standardization of biomethane potential tests. Water Sci. Technol. 74, 2515-2522. https://doi.org/10.2166/wst.2016.336

Jeung, J.H., Chung, W.J., Chang, S.W., 2019. Evaluation of Anaerobic Co-Digestion to Enhance the Efficiency of Livestock Manure Anaerobic Digestion. Sustain. . https://doi.org/10.3390/su11247170

Kacprzak, A., Krzystek, L., Paździor, K., Ledakowicz, S., 2012. Investigation of kinetics of anaerobic digestion of Canary grass. Chem. Pap. 66, 550-555. https://doi.org/10.2478/s11696-012-0136-4

Khoufi, S., Louhichi, A., Sayadi, S., 2015. Optimization of anaerobic co-digestion of olive mill wastewater and liquid poultry manure in batch condition and semi-continuous $\begin{array}{lllll}\text { jet-loop } & \text { reactor. } & \text { Bioresour. } & \text { Technol. }\end{array}$ https://doi.org/10.1016/j.biortech.2015.01.092

Kouakou, N.D.V., Grongnet, J.-F., Assidjo, N.E., Thys, E., Marnet, P.-G., Catheline, D., Legrand, P., Kouba, M., 2013. Effect of a supplementation of Euphorbia heterophylla on nutritional meat quality of Guinea pig (Cavia porcellus L.). Meat Sci. 93, 821-826. https://doi.org/10.1016/j.meatsci.2012.11.036

Lay, J.-J., Li, Y.-Y., Noike, T., 1997. Influences of pH and moisture content on the methane production in high-solids sludge digestion. Water Res. 31, 1518-1524. https://doi.org/10.1016/S0043-1354(96)00413-7

Li, L., He, Q., Zhao, X., Wu, D., Wang, X., Peng, X., 2018. Anaerobic digestion of food waste: Correlation of kinetic parameters with operational conditions and process performance. Biochem. Eng. J. 130, 1-9. https://doi.org/10.1016/j.bej.2017.11.003

Li, L., Kong, X., Yang, F., Li, D., Yuan, Z., Sun, Y., 2012. Biogas Production Potential 
and Kinetics of Microwave and Conventional Thermal Pretreatment of Grass. Appl. Biochem. Biotechnol. 166, 1183-1191. https://doi.org/10.1007/s12010-011-9503-9

Li, Y., Feng, L., Zhang, R., He, Y., Liu, X., Xiao, X., Ma, X., Chen, C., Liu, G., 2013a. Influence of Inoculum Source and Pre-incubation on Bio-Methane Potential of Chicken Manure and Corn Stover. Appl. Biochem. Biotechnol. 171, 117-127. https://doi.org/10.1007/s12010-013-0335-7

Li, Y., Zhang, R., Chen, C., Liu, G., He, Y., Liu, X., 2013b. Biogas production from codigestion of corn stover and chicken manure under anaerobic wet, hemi-solid-, and solidstate conditions. Bioresour. Technol. 149, 406-412.

\section{https://doi.org/10.1016/j.biortech.2013.09.091}

Li, Yangyang, Li, Yu, Zhang, D., Li, G., Lu, J., Li, S., 2016. Solid state anaerobic codigestion of tomato residues with dairy manure and corn stover for biogas production. Bioresour. Technol. 217, 50-55. https://doi.org/10.1016/j.biortech.2016.01.111

Lima, D.R.S., Adarme, O.F.H., Baêta, B.E.L., Gurgel, L.V.A., de Aquino, S.F., 2018. Influence of different thermal pretreatments and inoculum selection on the biomethanation of sugarcane bagasse by solid-state anaerobic digestion: A kinetic analysis. Ind. Crops Prod. 111, 684-693. https://doi.org/10.1016/j.indcrop.2017.11.048

Liu, C., Wang, J., Ji, X., Qian, H., Huang, L., Lu, X., 2016. The biomethane producing potential in China: A theoretical and practical estimation. Chinese J. Chem. Eng. 24, 920 928. https://doi.org/10.1016/j.cjche.2015.12.025

Lu, X., Zhen, G., Liu, Y., Hojo, T., Estrada, A.L., Li, Y.-Y., 2014. Long-term effect of the antibiotic cefalexin on methane production during waste activated sludge anaerobic digestion. $\quad$ Bioresour. $\quad$ Technol. 169, 644-651. https://doi.org/10.1016/j.biortech.2014.07.056

Ma, G., Ndegwa, P., Harrison, J.H., Chen, Y., 2020. Methane yields during anaerobic codigestion of animal manure with other feedstocks: A meta-analysis. Sci. Total Environ. 728, 138224. https://doi.org/10.1016/j.scitotenv.2020.138224 
Maletić, S., Murenji, S., Agbaba, J., Rončević, S., Kragulj Isakovski, M., Molnar Jazić, J., Dalmacija, B., 2018. Potential for anaerobic treatment of polluted sediment. J. Environ. Manage. 214, 9-16. https://doi.org/10.1016/j.jenvman.2018.02.029

Masse, D.I., Croteau, F., Patni, N.K., Masse, L., 2003. METHANE EMISSIONS FROM DAIRY COW AND SWINE MANURE SLURRIES STORED AT $10^{\wedge} \mathrm{oC}$ AND $15^{\wedge} \mathrm{oC}$. Can. Biosyst. Eng. 45, 1-6.

Mata-Alvarez, J., Macé, S., Llabrés, P., 2000. Anaerobic digestion of organic solid wastes. An overview of research achievements and perspectives. Bioresour. Technol. 74, 3-16. https://doi.org/https://doi.org/10.1016/S0960-8524(00)00023-7

Melby, C.L., Orozco, F., Averett, J., Muñoz, F., Romero, M.J., Barahona, A., 2020. Agricultural Food Production Diversity and Dietary Diversity among Female Small Holder Farmers in a Region of the Ecuadorian Andes Experiencing Nutrition Transition. Nutrients 12, 2454.

Meneses-Quelal, W.O., Velázquez-Martí, B., Gaibor-Chávez, J., Niño-Ruiz, Z., 2021. Biochemical potential of methane (BMP) of camelid waste and the Andean region agricultural crops. Renew. Energy 168, 406-415. https://doi.org/10.1016/j.renene.2020.12.071

Moset, V., Al-zohairi, N., Møller, H.B., 2015. The impact of inoculum source, inoculum to substrate ratio and sample preservation on methane potential from different substrates. Biomass and Bioenergy 83, 474-482. https://doi.org/10.1016/j.biombioe.2015.10.018

Naik, S.N., Goud, V. V, Rout, P.K., Dalai, A.K., 2010. Production of first and second generation biofuels: A comprehensive review. Renew. Sustain. Energy Rev. 14, 578-597. https://doi.org/10.1016/j.rser.2009.10.003

Nielfa, A., Cano, R., Fdz-Polanco, M., 2015. Theoretical methane production generated by the co-digestion of organic fraction municipal solid waste and biological sludge. Biotechnol. Reports 5, 14-21. https://doi.org/10.1016/j.btre.2014.10.005

Omambia, A.N., Shemsanga, C., Hernandez, I.A.S., 2017. Climate change impacts, vulnerability, and adaptation in East Africa (EA) and South America (SA). Handb. Clim. 
Chang. Mitig. Adapt. Springer Int. Publ. Switz. 749-799.

Orlando, M.-Q., Borja, V.-M., 2020. Pretreatment of Animal Manure Biomass to Improve Biogas Production: A Review. Energies 13, 3573.

Pagés-Díaz, J., Pereda-Reyes, I., Taherzadeh, M.J., Sárvári-Horváth, I., Lundin, M., 2014. Anaerobic co-digestion of solid slaughterhouse wastes with agro-residues: Synergistic and antagonistic interactions determined in batch digestion assays. Chem. Eng. J. 245, 89-98. https://doi.org/10.1016/j.cej.2014.02.008

Parra-Orobio, B.A., Donoso-Bravo, A., Ruiz-Sánchez, J.C., Valencia-Molina, K.J., Torres-Lozada, P., 2018. Effect of inoculum on the anaerobic digestion of food waste accounting for the concentration of trace elements. Waste Manag. 71, 342-349. https://doi.org/10.1016/j.wasman.2017.09.040

Pearse, L.F., Hettiaratchi, J.P., Kumar, S., 2018. Towards developing a representative biochemical methane potential (BMP) assay for landfilled municipal solid waste - A review. Bioresour. Technol. 254, 312-324. https://doi.org/10.1016/j.biortech.2018.01.069

Pellera, F.-M., Gidarakos, E., 2016. Effect of substrate to inoculum ratio and inoculum type on the biochemical methane potential of solid agroindustrial waste. J. Environ. Chem. Eng. 4, 3217-3229. https://doi.org/10.1016/j.jece.2016.05.026

Pérez, I., Garfí, M., Cadena, E., Ferrer, I., 2014. Technical, economic and environmental assessment of household biogas digesters for rural communities. Renew. Energy 62, $313-$ 318. https://doi.org/10.1016/j.renene.2013.07.017

Pitt, R.E., Cross, T.L., Pell, A.N., Schofield, P., Doane, P.H., 1999. Use of in vitro gas production models in ruminal kinetics. Math. Biosci. 159, 145-163. https://doi.org/10.1016/S0025-5564(99)00020-6

Polizzi, C., Alatriste-Mondragón, F., Munz, G., 2017. Modeling the Disintegration Process in Anaerobic Digestion of Tannery Sludge and Fleshing . Front. Environ. Sci. 
Quintero, M., Castro, L., Ortiz, C., Guzmán, C., Escalante, H., 2012. Enhancement of starting up anaerobic digestion of lignocellulosic substrate: fique's bagasse as an example. Bioresour. Technol. 108, 8-13. https://doi.org/10.1016/j.biortech.2011.12.052

Rahman, M.A., Møller, H.B., Saha, C.K., Alam, M.M., Wahid, R., Feng, L., 2017. Optimal ratio for anaerobic co-digestion of poultry droppings and lignocellulosic-rich substrates for enhanced biogas production. Energy Sustain. Dev. 39, 59-66. https://doi.org/10.1016/j.esd.2017.04.004

Raposo, F., Banks, C.J., Siegert, I., Heaven, S., Borja, R., 2006. Influence of inoculum to substrate ratio on the biochemical methane potential of maize in batch tests. Process Biochem. 41, 1444-1450. https://doi.org/10.1016/j.procbio.2006.01.012

Raposo, F., Borja, R., Martín, M.A., Martín, A., de la Rubia, M.A., Rincón, B., 2009. Influence of inoculum-substrate ratio on the anaerobic digestion of sunflower oil cake in batch mode: Process stability and kinetic evaluation. Chem. Eng. J. 149, 70-77. https://doi.org/10.1016/j.cej.2008.10.001

Raposo, F., Fernández-Cegrí, V., De la Rubia, M.A., Borja, R., Béline, F., Cavinato, C., Demirer, G., Fernández, B., Fernández-Polanco, M., Frigon, J.C., Ganesh, R., Kaparaju, P., Koubova, J., Méndez, R., Menin, G., Peene, A., Scherer, P., Torrijos, M., Uellendahl, H., Wierinck, I., de Wilde, V., 2011. Biochemical methane potential (BMP) of solid organic substrates: evaluation of anaerobic biodegradability using data from an international interlaboratory study. J. Chem. Technol. Biotechnol. 86, 1088-1098. https://doi.org/10.1002/jctb.2622

Rivera-Parra, J.L., Peña-Loyola, P.J., 2020. Potential high-quality growing tea regions in Ecuador: an alternative cash crop for Ecuadorian small landholders. J. Sci. Food Agric. 100, 1827-1831. https://doi.org/10.1002/jsfa.10225

Roberts, K.P., Heaven, S., Banks, C.J., 2016. Comparative testing of energy yields from micro-algal biomass cultures processed via anaerobic digestion. Renew. Energy 87, 744753. https://doi.org/10.1016/j.renene.2015.11.009

Sánchez-Macías, D., Barba-Maggi, L., Morales-delaNuez, A., Palmay-Paredes, J., 2018. Guinea pig for meat production: A systematic review of factors affecting the production, carcass and meat quality. Meat Sci. 143, 165-176. https://doi.org/10.1016/j.meatsci.2018.05.004 
Seppälä, M., Laine, A., Rintala, J., 2013. Screening of novel plants for biogas production in northern conditions. Bioresour. Technol. 139, 355-362. https://doi.org/10.1016/j.biortech.2013.04.014

Sheinbaum-Pardo, C., Ruiz, B.J., 2012. Energy context in Latin America. Energy 40, 3946. https://doi.org/10.1016/j.energy.2011.10.041

Shen, J., Zheng, Q., Zhang, R., Chen, C., Liu, G., 2019. Co-pretreatment of wheat straw by potassium hydroxide and calcium hydroxide: Methane production, economics, and energy potential analysis. J. Environ. Manage. 236, 720-726. https://doi.org/10.1016/j.jenvman.2019.01.046

Shrestha, S., Fonoll, X., Khanal, S.K., Raskin, L., 2017. Biological strategies for enhanced hydrolysis of lignocellulosic biomass during anaerobic digestion: Current status and future perspectives. Bioresour. Technol. 245, 1245-1257. https://doi.org/10.1016/j.biortech.2017.08.089

Silva, K.C.D. da, Amorim, M.C.C. de, Galvão, R.S., Gonçalves, Y.B. de O., Silva, P.T. de S. e, Barros, E.S.C., 2020. Effect of the inoculum/substrate ratio on the biochemical methane potential (BMP) of grape marc. Rev. Ambient. Água.

Sun, J., Li, Z., Zhou, X., Wang, X., Liu, T., Cheng, S., 2019. Investigation on methane yield of wheat husk anaerobic digestion and its enhancement effect by liquid digestate pretreatment. Anaerobe 59, 92-99. https://doi.org/10.1016/j.anaerobe.2019.05.009

Ugwu, S.N., Enweremadu, C.C., 2019. Biodegradability and kinetic studies on biomethane production from okra (Abelmoschus esculentus) waste . South African J. Sci.

VDI, V.D.I., 2006. 4630: Fermentation of organic materials-Characterisation of the substrate, sampling, collection of material data, fermentation tests. Verein Dtsch. Ingenieure (VDI), Ed. VDI Handb. Energietechnik. Berlin Beuth Verlag GmbH 44-59.

Velázquez-Martí, B., Meneses, O., Gaibor, J., Niño, Z., 2018. Review of Mathematical Models for the Anaerobic Digestion Process. https://doi.org/10.5772/intechopen.80815 
Vivekanand, V., Mulat, D.G., Eijsink, V.G.H., Horn, S.J., 2018. Synergistic effects of anaerobic co-digestion of whey, manure and fish ensilage. Bioresour. Technol. 249, 3541. https://doi.org/10.1016/j.biortech.2017.09.169

Wang, K., Yun, S., Xing, T., Li, B., Abbas, Y., Liu, X., 2021. Binary and ternary trace elements to enhance anaerobic digestion of cattle manure: Focusing on kinetic models for biogas production and digestate utilization. Bioresour. Technol. 323, 124571. https://doi.org/10.1016/j.biortech.2020.124571

Ware, A., Power, N., 2017. Modelling methane production kinetics of complex poultry slaughterhouse wastes using sigmoidal growth functions. Renew. Energy 104, 50-59. https://doi.org/10.1016/j.renene.2016.11.045

Wei, S., Zhang, H., Cai, X., Xu, J., Fang, J., Liu, H., 2014. Psychrophilic anaerobic codigestion of highland barley straw with two animal manures at high altitude for enhancing biogas production. Energy Convers. Manag. 88, 40-48. https://doi.org/10.1016/j.enconman.2014.08.018

Wu, X., Yao, W., Zhu, J., Miller, C., 2010. Biogas and $\mathrm{CH}_{4}$ productivity by co-digesting swine manure with three crop residues as an external carbon source. Bioresour. Technol. 101, 4042-4047. https://doi.org/10.1016/j.biortech.2010.01.052

Zahan, Z., Georgiou, S., Muster, T.H., Othman, M.Z., 2018. Semi-continuous anaerobic co-digestion of chicken litter with agricultural and food wastes: A case study on the effect of carbon/nitrogen ratio, substrates mixing ratio and organic loading. Bioresour. Technol. 270, 245-254. https://doi.org/10.1016/j.biortech.2018.09.010

Zhang, W., Lang, Q., Fang, M., Li, X., Bah, H., Dong, H., Dong, R., 2017. Combined effect of crude fat content and initial substrate concentration on batch anaerobic digestion characteristics of food waste. Bioresour. Technol. 232, 304-312. https://doi.org/10.1016/j.biortech.2017.02.039

Zhang, W., Wei, Q., Wu, S., Qi, D., Li, W., Zuo, Z., Dong, R., 2014. Batch anaerobic codigestion of pig manure with dewatered sewage sludge under mesophilic conditions. Appl. Energy 128, 175-183. https://doi.org/10.1016/j.apenergy.2014.04.071 
Zhao, X., Li, L., Wu, D., Xiao, T., Ma, Y., Peng, X., 2019. Modified Anaerobic Digestion Model No. 1 for modeling methane production from food waste in batch and semicontinuous anaerobic digestions. Bioresour. Technol. 271, 109-117. https://doi.org/10.1016/j.biortech.2018.09.091

Zhen, G., Lu, X., Kobayashi, T., Li, Y.-Y., Xu, K., Zhao, Y., 2015. Mesophilic anaerobic co-digestion of waste activated sludge and Egeria densa: Performance assessment and $\begin{array}{lllll}\text { kinetic } & \text { analysis. } & \text { Appl. } & \text { 78-86. }\end{array}$ https://doi.org/10.1016/j.apenergy.2015.03.038

Zhen, G., Lu, X., Li, Y.-Y., Zhao, Y., 2014. Combined electrical-alkali pretreatment to increase the anaerobic hydrolysis rate of waste activated sludge during anaerobic digestion. Appl. Energy 128, 93-102. https://doi.org/10.1016/j.apenergy.2014.04.062

Zou, H., Chen, Y., Shi, J., Zhao, T., Yu, Q., Yu, S., Shi, D., Chai, H., Gu, L., He, Q., Ai, H., 2018. Mesophilic anaerobic co-digestion of residual sludge with different lignocellulosic wastes in the batch digester. Bioresour. Technol. 268, 371-381. https://doi.org/10.1016/j.biortech.2018.07.129

Zwietering, M.H., Jongenburger, I., Rombouts, F.M., van \&\#039;t Riet, K., 1990. Modeling of the Bacterial Growth Curve. Appl. Environ. Microbiol. 56, 1875 LP - 1881.

\section{FIGURES}



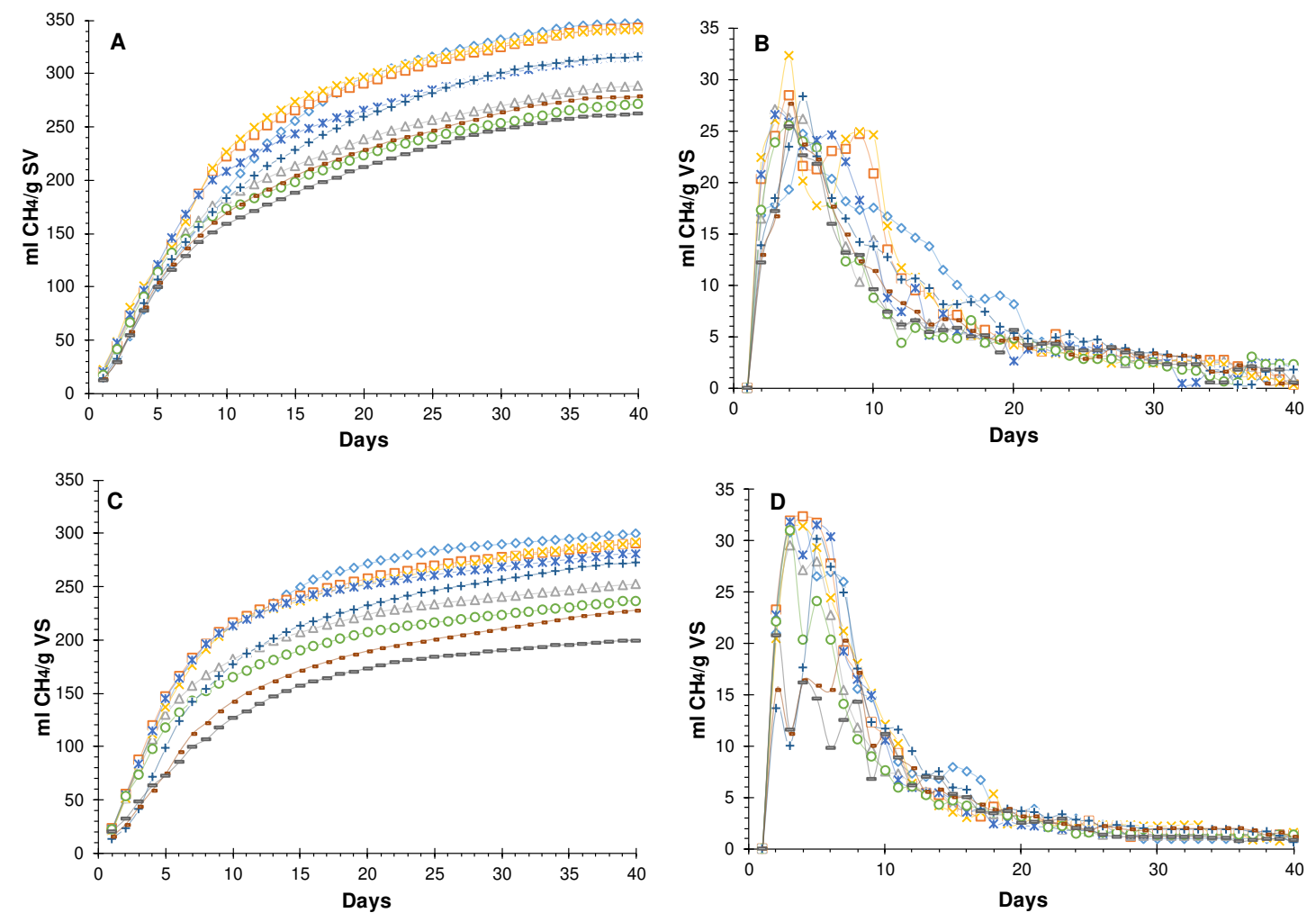

$\diamond$ CY-AM $(25: 75)$

口- CY-AM (50:50)

$\triangle$ CY-AM (75:25)

- C- CY-QU (75:25)

+ CY-TR (25:75)

- CY-TR (50:50)

- CY-QU (25:75)

- -CY-QU (50:50)

Figure 1. Daily and cumulative profiles of $\mathrm{CH}_{4}$ production as a function of time, for trials with different IRS.

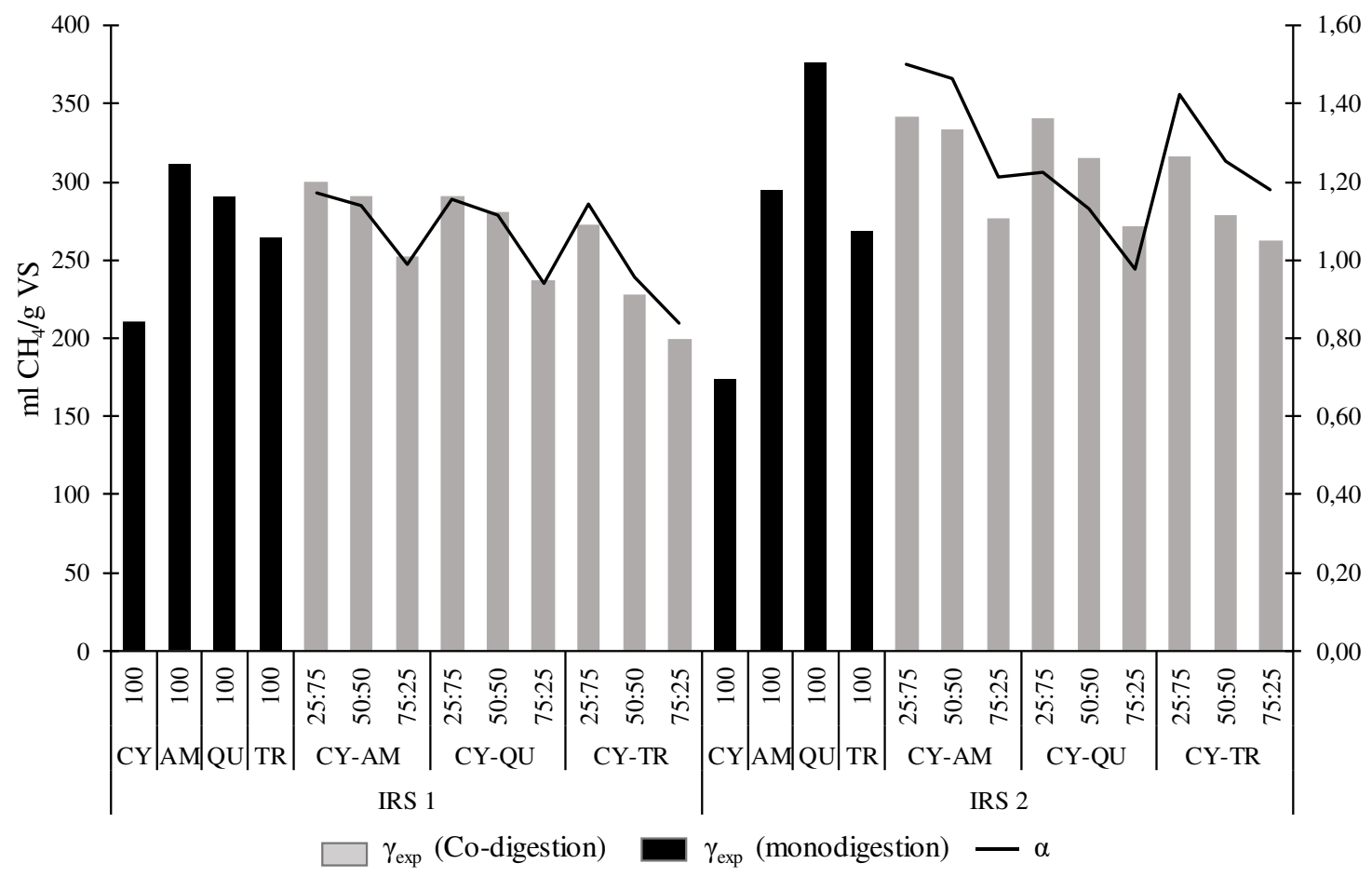

Figure 2. Synergy index of the co-digestion of guinea pig manure with different lignocellulosic co-substrates. $\alpha>1$ indicates synergistic effect and $\alpha<1$ indicates antagonistic effect.

(Source: Adapted from Meneses et al. (2021)). 


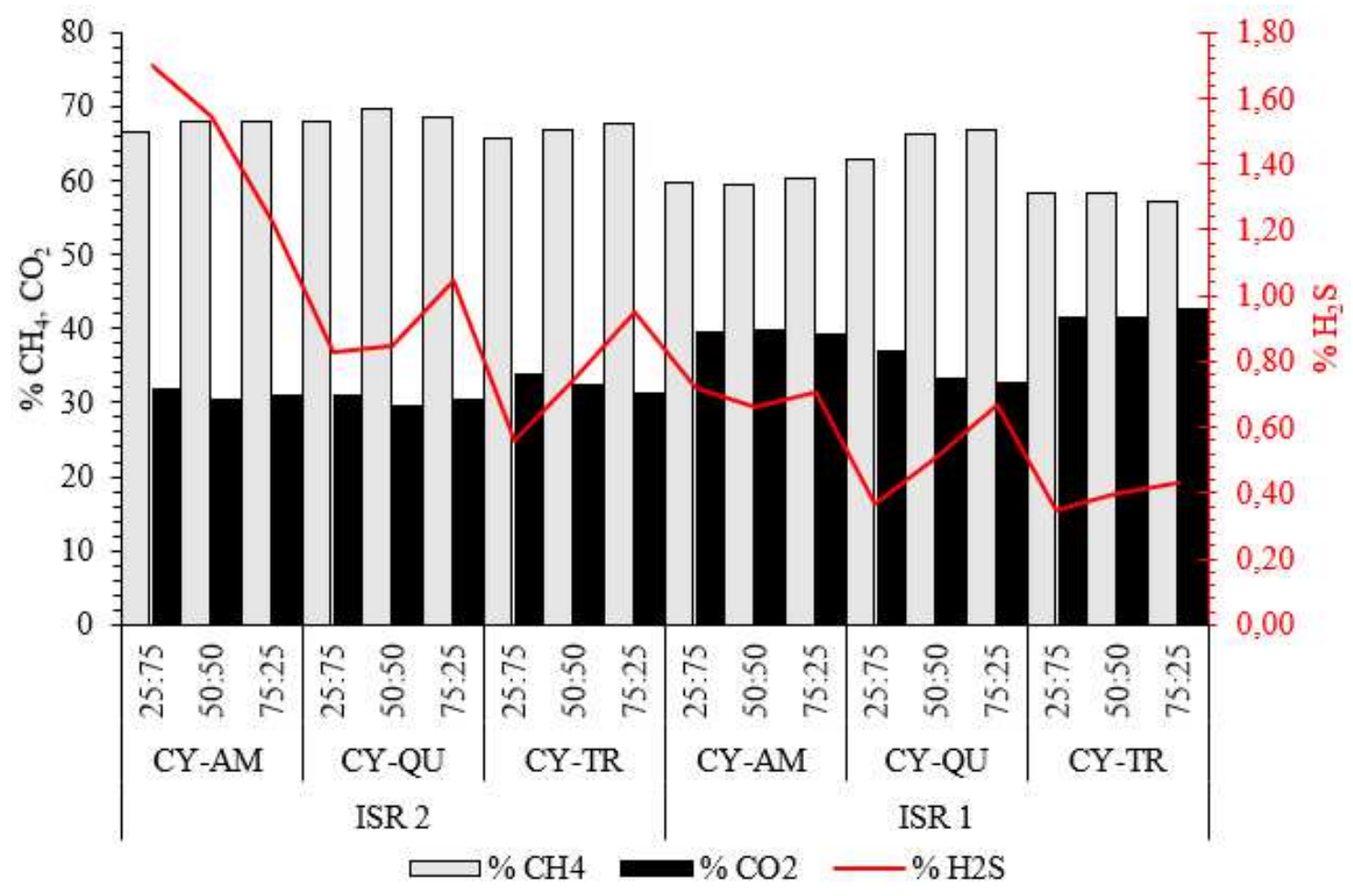

Figure 3. Percentages of $\mathrm{CH}_{4}, \mathrm{CO}_{2}$ and $\mathrm{H}_{2} \mathrm{~S}$ from $\mathrm{CY}$ manure biogas
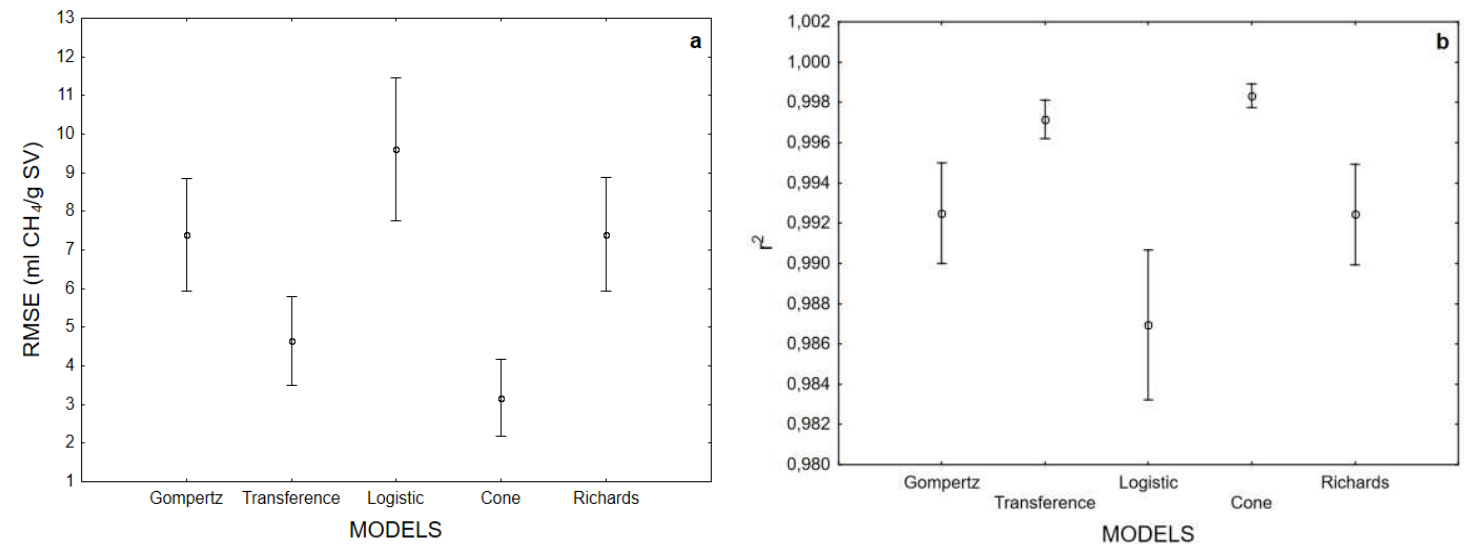

Figure 4. LSD (Least significant difference) intervals of the analysis of variance at the $95 \%$ confidence level for the comparison of the RMSE, the $\mathrm{r}^{2}$ of the different models applied to the codigestion of CY manure.

\section{TABLES}

Table 1. Characterization of substrates, co-substrates and inoculum

\begin{tabular}{|c|c|c|c|c|c|c|}
\hline \multirow{2}{*}{ Parameters } & \multirow{2}{*}{ Units } & \multirow{2}{*}{$\begin{array}{c}\text { Substrates } \\
\text { CY }\end{array}$} & \multicolumn{3}{|c|}{ Co-substrates } & \multirow{2}{*}{$\begin{array}{c}\text { Inóculo } \\
\text { IN } \\
\end{array}$} \\
\hline & & & $\mathbf{A M}$ & QU & TR & \\
\hline TS & $\%$ & $33.9(1.7)$ & $88.2(0.1)$ & $87.0(0.1)$ & $92.6(0.1)$ & $3.9(0.1)$ \\
\hline VS & $\%$ & $24.6(0.9)$ & $65.9(0.8)$ & $50.8(0.7)$ & $71.5(0.7)$ & $2.3(0.7)$ \\
\hline VS/TS & - & 0.73 & 0.75 & 0.58 & 0.77 & 0.59 \\
\hline Ashes & $\%$ & $13.1(0.1)$ & $8.4(0.1)$ & $30.3(1.4)$ & $11.8(0.1)$ & $55.6(0.2)$ \\
\hline $\mathbf{N}$ & $\%$ & $2.3(1.0)$ & $3.3(0.9)$ & $2.2(0.9)$ & $1.7(0.7)$ & $3.4(0.1)$ \\
\hline C & $\%$ & $39.5(1.2)$ & 42.9 (1.9) & $30.7(1.7)$ & 48.9 (1.6) & $25.0(1.2)$ \\
\hline $\mathbf{H}$ & $\%$ & $4.6(0.5$ & $6.5(0.8)$ & $6.4(0.9)$ & $6.1(0.5)$ & $2.1(0.1)$ \\
\hline
\end{tabular}




\begin{tabular}{lrrrrrr}
\hline $\mathbf{O}$ & $\%$ & $39.7(1.2)$ & $38.6(1.9)$ & $29.8(1.7)$ & $31.1(1.6)$ & $12.9(1.2)$ \\
$\mathbf{S}$ & $\%$ & $0.4(0.0)$ & $0.2(0.0)$ & $0.6(0.1)$ & $0.5(0.0)$ & $0.7(0.0)$ \\
$\mathbf{C} / \mathbf{N}$ & - & $15.3(0.8)$ & $12.9(0.8)$ & $12.0(0.9)$ & $29.6(0.8)$ & $7.5(0.7)$ \\
\hline
\end{tabular}


Table 2. Kinetic parameters of methane from guinea pig manure co-digestion

\begin{tabular}{|c|c|c|c|c|c|c|c|c|c|c|c|c|c|c|c|c|c|c|c|}
\hline \multirow{3}{*}{ Model } & \multirow{3}{*}{ Parameters } & \multicolumn{9}{|c|}{ ISR of 2} & \multicolumn{9}{|c|}{ ISR of 1} \\
\hline & & \multicolumn{3}{|c|}{ CY-AM } & \multicolumn{3}{|c|}{ CY-QU } & \multicolumn{3}{|c|}{ CY-TR } & \multicolumn{3}{|c|}{ CY-AM } & \multicolumn{3}{|c|}{ CY-QU } & \multicolumn{3}{|c|}{ CY-TR } \\
\hline & & $25: 75$ & 50:50 & $75: 25$ & $25: 75$ & 50:50 & $75: 25$ & $25: 75$ & $50: 50$ & $75: 25$ & $25: 75$ & $50: 50$ & $75: 25$ & 25:75 & $50: 50$ & $75: 25$ & $25: 75$ & $50: 50$ & $75: 25$ \\
\hline \multirow{5}{*}{ GOMPERTZ } & $\mathbf{M}_{\mathbf{e}}$ & 341,3 & 324,1 & 273,9 & 323,9 & 298,7 & 259,2 & 302,1 & 270,6 & 253,7 & 180,7 & 174,1 & 150,2 & 184,5 & 149,9 & 140,9 & 160,7 & 153,3 & 124,6 \\
\hline & $v_{\max }$ & 17,13 & 19,09 & 13,67 & 20,8 & 17,02 & 13,02 & 14,86 & 13,75 & 11,98 & 13,27 & 13,63 & 10,62 & 14,67 & 13,01 & 8,85 & 11,02 & 9,12 & 7,3 \\
\hline & $t_{\text {lag }}$ & 0,41 & $-0,89$ & $-2,72$ & $-0,53$ & $-1,76$ & $-2,72$ & $-1,09$ & $-1,61$ & $-2,16$ & $-1,13$ & $-1,5$ & $-1,78$ & $-1,37$ & $-0,88$ & $-2,43$ & $-0,27$ & $-0,86$ & $-1,34$ \\
\hline & $\mathbf{r}^{2}$ & 0,998 & 0,993 & 0,986 & 0,995 & 0,989 & 0,987 & 0,992 & 0,99 & 0,988 & 0,984 & 0,969 & 0,977 & 0,965 & 0,974 & 0,975 & 0,981 & 0,985 & 0,995 \\
\hline & RMSE & 5,88 & 10,41 & 11,31 & 8,65 & 11,09 & 10,27 & 10,18 & 10,07 & 10,05 & 5,48 & 7 & 5,31 & 7,95 & 5,61 & 5,09 & 5,91 & 5,04 & 2,16 \\
\hline \multirow{5}{*}{ TRANSFERENCE } & $\mathbf{M}_{\mathrm{e}}$ & 372,8 & $*$ & 283,1 & $*$ & 308,6 & 267,4 & 319,8 & 282,4 & 264,9 & 184,2 & 176,7 & 152,8 & 187,5 & 152,4 & 143,5 & 166,1 & 159,6 & 129,1 \\
\hline & $v_{\max }$ & 25,95 & $*$ & 25,86 & $*$ & 31,31 & 24,74 & 25,45 & 24,69 & 21,86 & 24,94 & 26,51 & 20,63 & 28,2 & 24,36 & 17,38 & 19,14 & 15,87 & 12,96 \\
\hline & $t_{\text {lag }}$ & 0,98 & $*$ & $-0,28$ & $*$ & 0,12 & $-0,29$ & 0,57 & 0,33 & 0,09 & 0,35 & 0,13 & 0,01 & 0,18 & 0,38 & $-0,3$ & 0,87 & 0,53 & 0,17 \\
\hline & $\mathbf{r}^{2}$ & 0,995 & * & 0,995 & $*$ & 0,996 & 0,995 & 0,999 & 0,998 & 0,996 & 0,998 & 0,993 & 0,996 & 0,992 & 0,995 & 0,995 & 0,997 & 0,997 & 0,999 \\
\hline & RMSE & 10,04 & $*$ & 7,04 & $*$ & 6,33 & 6,26 & 4,31 & 4,96 & 5,58 & 2,48 & 4,52 & 3,11 & 5,5 & 3,61 & 3,12 & 3,46 & 2,93 & 1,12 \\
\hline \multirow{5}{*}{ LOGISTIC } & $\mathbf{M e}_{\mathbf{e}}$ & 331,7 & 318,6 & 269,8 & 318,7 & 294,5 & 255,6 & 295,6 & 265,9 & 249,3 & 179,1 & 172,7 & 148,9 & 182,9 & 148,7 & 139,5 & 158,6 & 150,8 & 122,8 \\
\hline & $v_{\max }$ & 16,83 & 17,66 & 12,01 & 19,52 & 15,2 & 11,4 & 13,7 & 12,37 & 10,69 & 11,79 & 11,92 & 9,27 & 13 & 11,67 & 7,66 & 10,12 & 8,38 & 6,68 \\
\hline & $\mathbf{t}_{\text {lag }}$ & 0,71 & $-1,26$ & $-3,8$ & $-0,71$ & $-2,52$ & $-3,83$ & $-1,54$ & $-2,32$ & $-3,05$ & $-1,74$ & $-2,23$ & $-2,6$ & -2 & $-1,35$ & $-3,45$ & $-0,61$ & $-1,28$ & $-1,78$ \\
\hline & $\mathbf{r}^{2}$ & 0,997 & 0,986 & 0,978 & 0,99 & 0,982 & 0,979 & 0,986 & 0,983 & 0,981 & 0,985 & 0,976 & 0,981 & 0,974 & 0,979 & 0,98 & 0,983 & 0,986 & 0,994 \\
\hline & RMSE & 7,52 & 14,3 & 14,11 & 12,18 & 14,47 & 12,88 & 14,02 & 13,31 & 12,85 & 7,51 & 8,68 & 6,79 & 9,63 & 7,09 & 6,42 & 7,96 & 6,92 & 3,58 \\
\hline \multirow{5}{*}{ CONE } & $\mathbf{M}_{\mathrm{e}}$ & 394,8 & 372,5 & 340,9 & 362,3 & 350,5 & 319,9 & 368,3 & 327,6 & 318,6 & 198,2 & 191,2 & 167,4 & 203,3 & 161,7 & 162 & 176,9 & 175,1 & 143 \\
\hline & $\mathbf{k}$ & 0,08 & 0,12 & 0,1 & 0,13 & 0,12 & 0,11 & 0,09 & 0,1 & 0,09 & 0,17 & 0,2 & 0,18 & 0,2 & 0,2 & 0,16 & 0,14 & 0,12 & 0,12 \\
\hline & $\mathbf{n}$ & 1,61 & 1,4 & 1,08 & 1,51 & 1,25 & 1,09 & 1,3 & 1,24 & 1,14 & 1,43 & 1,34 & 1,29 & 1,34 & 1,48 & 1,17 & 1,59 & 1,42 & 1,35 \\
\hline & $\mathbf{r}^{2}$ & 0,997 & 0,986 & 0,978 & 0,99 & 0,982 & 0,979 & 0,986 & 0,983 & 0,981 & 1 & 0,998 & 0,999 & 0,997 & 0,998 & 0,999 & 0,998 & 0,999 & 0,999 \\
\hline & RMSE & 8,85 & 4,6 & 4,4 & 5,13 & 4,06 & 3,93 & 3,35 & 3,62 & 4,13 & 1,16 & 2,53 & 1,46 & 3,51 & 2,19 & 1,44 & 2,62 & 2,1 & 1,37 \\
\hline \multirow{6}{*}{ RICHARDS } & $M_{e}$ & 340,76 & 324,23 & 275,07 & 323,84 & 298,86 & 259,33 & 301,88 & 271,07 & 253,45 & 180,72 & 173,97 & 150,62 & 184,54 & 150,49 & 140,84 & 160,75 & 153,25 & 124,68 \\
\hline & d & 0,008 & 0,004 & 0,002 & 0,005 & 0,004 & 0,004 & 0,005 & 0,005 & 0,001 & 0,005 & 0,002 & 0,001 & 0,003 & $-0,028$ & 0,004 & 0,004 & 0,004 & 0,005 \\
\hline & $v_{\max }$ & 12,14 & 6,78 & 2,13 & 10,75 & 7,22 & 4,63 & 6,72 & 6,1 & 1,07 & 5,98 & 3,23 & 0,56 & 3,7 & $-35,95$ & 3,95 & 4,48 & 3,35 & 3,91 \\
\hline & $\mathbf{t}_{\text {lag }}$ & 0,42 & $-0,92$ & $-2,88$ & $-0,53$ & $-1,83$ & $-2,78$ & $-1,09$ & $-1,7$ & $-2,13$ & $-1,15$ & $-1,51$ & $-1,96$ & $-1,4$ & $-1,14$ & $-2,44$ & $-0,3$ & $-0,89$ & $-1,37$ \\
\hline & $\mathbf{r}^{2}$ & 0,998 & 0,993 & 0,986 & 0,995 & 0,989 & 0,987 & 0,992 & 0,99 & 0,988 & 0,998 & 0,984 & 0,988 & 0,982 & 0,987 & 0,987 & 0,991 & 0,992 & 0,998 \\
\hline & RMSE & 5,87 & 10,43 & 11,33 & 8,67 & 11,12 & 10,28 & 10,2 & 10,09 & 10,05 & 5,49 & 7,01 & 5,33 & 7,96 & 5,59 & 5,1 & 5,92 & 5,05 & 2,16 \\
\hline
\end{tabular}

NOTE: The (*) means that for these mixtures the model does not converge. 
Table 3. Co-digestion of animal manure residues with lignocellulosic residues present in the literature.

\begin{tabular}{cccc}
\hline $\begin{array}{c}\text { Raw } \\
\text { Materials }\end{array}$ & Mixing ratio & $\begin{array}{c}\text { Methane Production } \\
\text { ml/g VS }\end{array}$ & References \\
\hline CMA:CS & $25: 75$ & 218,8 & (Li et al., 2013) \\
RS: KW: GW & $57: 29: 14$ & 303,4 & (Chen et al., 2019) \\
DM:CS:TO & $54: 33: 13$ & 415,4 & (Li et al., 2016) \\
PD:WS & $70: 30$ & 330,1 & (Rahman et al., 2017) \\
PD:MG & $50: 50$ & 340,1 & (Rahman et al., 2017) \\
ESBP: PM & $25: 75$ & 212,4 & (Wei et al., 2014) \\
BS:TPM & $50: 50$ & 152,3 & (Wei et al., 2014) \\
BS:CM & $50: 50$ & $120-125$ & Data from this study \\
CY-AM & $25: 75$ & 341,9 & Data from this study \\
CY-QU & $25: 75$ & 341,1 & Data from this study \\
CY-TR & $25: 75$ & 315,9 & KW
\end{tabular}

Note: CS (corn stover), CMA (chicken manure), RS (residual sludge), KW (kitchen waste), GW (green waste from Garden branches and leaves), TO (tomato residues), DM (dairy manure), WS (wheat Straw), MG (meadow grass), PD (Poultry droppings), PM (pig manure), ESBP (sugar beet pulp), BS (barley Straw), TPM (Tibet pig manure) and CM (cow manure). 
Figures
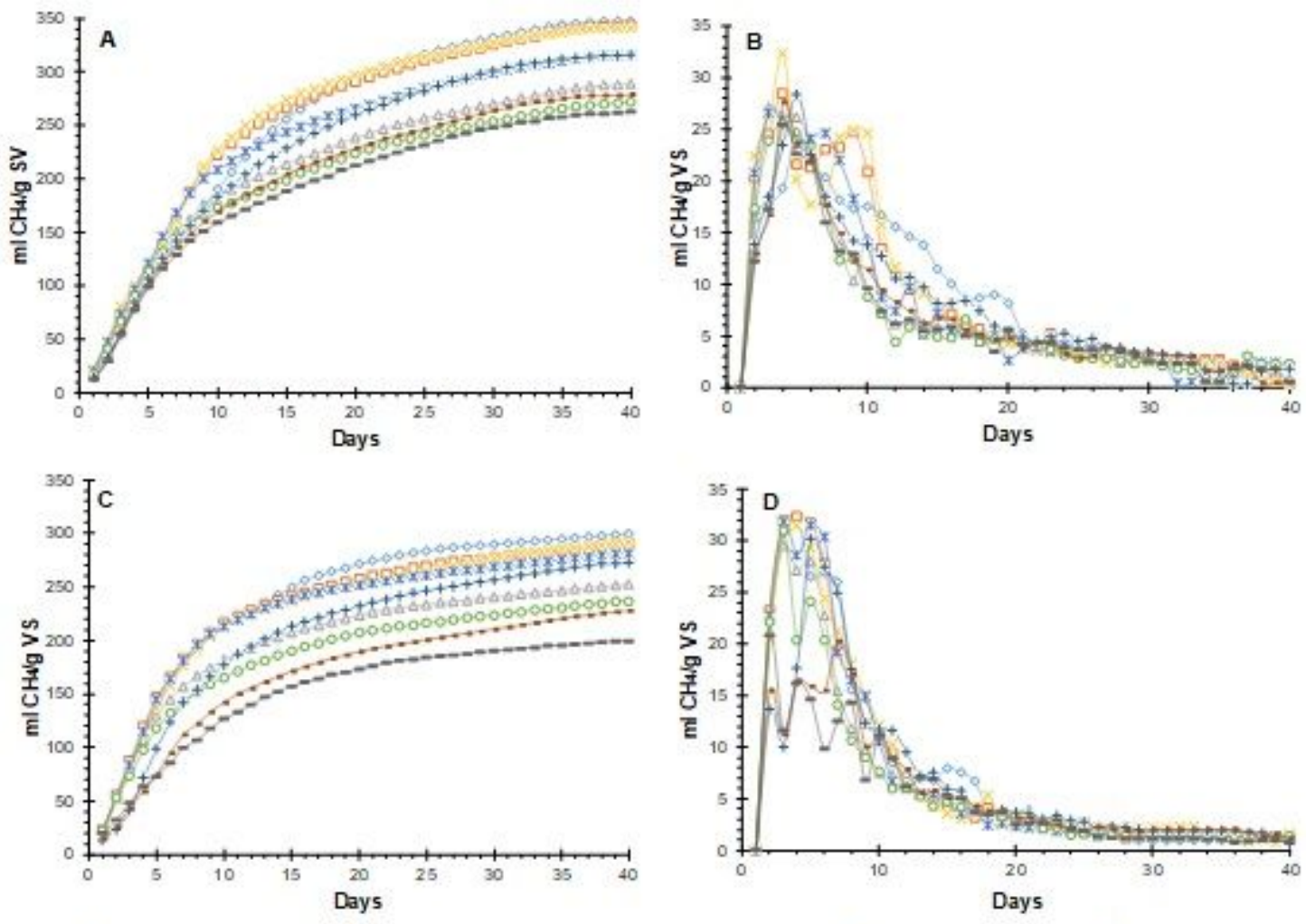

$\because$ CYAM (25.75)

口 CY-AM (50.50)
+ CY-TR (25.75)

$\triangle$ CY-AM (75.25)

* CY-CU (25:75)

× Cr.qu (50:50)

\section{Figure 1}

Daily and cumulative profiles of $\mathrm{CH} 4$ production as a function of time, for trials with different IRS.

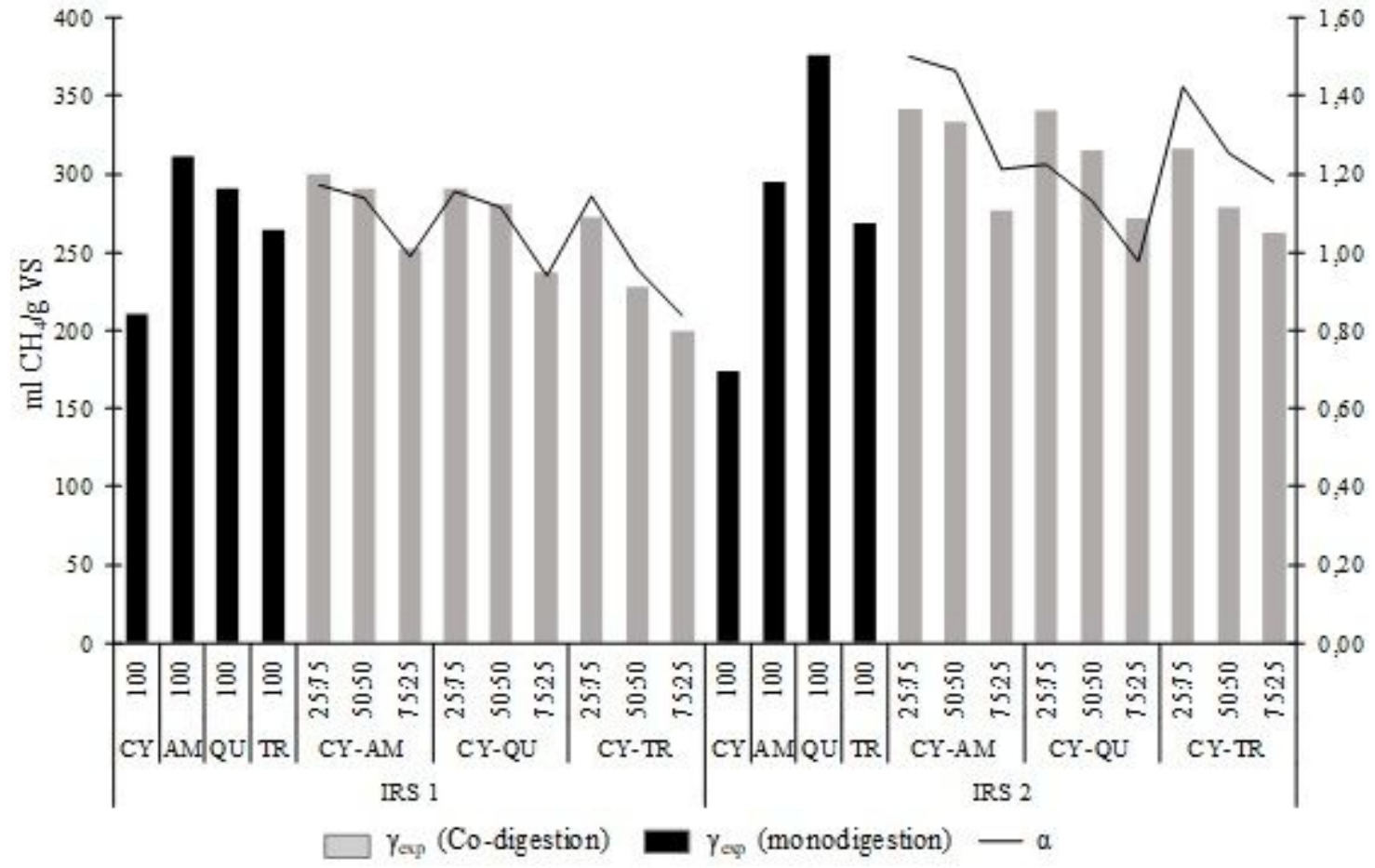

Figure 2 
Synergy index of the co-digestion of guinea pig manure with different lignocellulosic co-substrates. $a>1$ indicates synergistic effect and $a<1$ indicates antagonistic effect. (Source: Adapted from Meneses et al. (2021)).

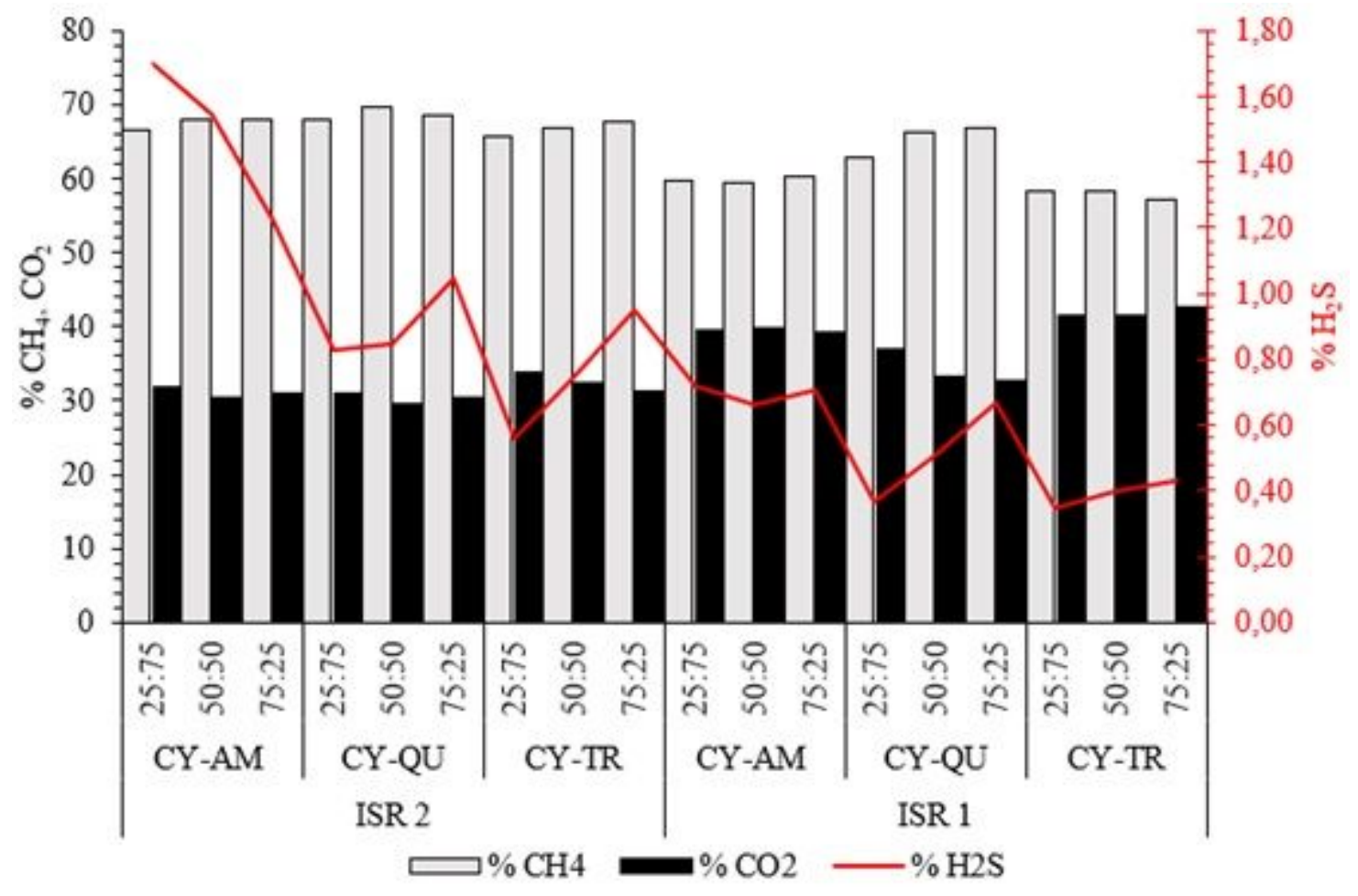

Figure 3

Percentages of $\mathrm{CH} 4, \mathrm{CO} 2$ and $\mathrm{H} 2 \mathrm{~S}$ from $\mathrm{CY}$ manure biogas
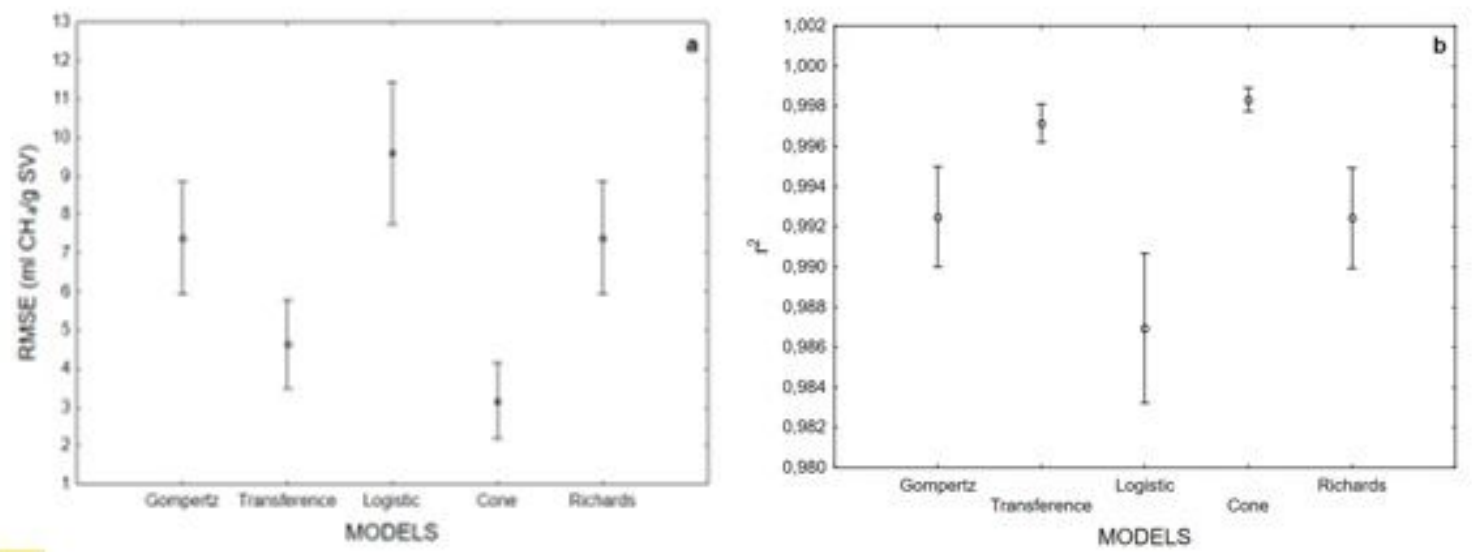

Figure 4

LSD (Least significant difference) intervals of the analysis of variance at the $95 \%$ confidence level for the comparison of the RMSE, the $\mathrm{r} 2$ of the different models applied to the co-digestion of $\mathrm{CY}$ manure. 